\title{
Deciphering the ozone-induced changes in cellular processes: a prerequisite for ozone risk assessment at the tree and forest levels
}

\author{
Yves Jolivet $^{1,2}$ - Matthieu Bagard ${ }^{3}$ - Mireille Cabané ${ }^{1,2}$ - Marie-Noëlle Vaultier ${ }^{1,2}$. \\ Anthony Gandin ${ }^{1,2} \cdot$ Dany Afif ${ }^{1,2} \cdot$ Pierre Dizengremel $^{1,2} \cdot$ Didier Le Thiec $^{2,1}$
}

Received: 17 April 2015 / Accepted: 19 August 2016 / Published online: 7 September 2016

(C) INRA and Springer-Verlag France 2016

\begin{abstract}
- Key message Ozone, one of the major atmospheric pollutants, alters tree growth, mainly by decreasing carbon assimilation and allocation to stems and roots. To date, the mechanisms of $\mathrm{O}_{3}$ impact at the cellular level have been investigated mainly on young trees grown in controlled or semi-controlled conditions. In the context of climate change, it is necessary to introduce a valuable defence parameter in the models that currently predict $\mathrm{O}_{3}$ impact on mature trees and the carbon sequestration capacity of forest ecosystems.

- Context Air pollution is an important factor that affects negatively forest ecosystems. Among oxidative air pollutants, ozone is considered as the most toxic in terms of impact on vegetation.
\end{abstract}

Handling editor: Jean-Michel Leban

Contribution of the co-authors Yves Jolivet, Matthieu Bagard, Mireille Cabane, Marie-Noëlle Vaultier, Anthony Gandin, Dany Afif, Pierre Dizengremel, and Didier Le Thiec contributed to the writing of this review.

Yves Jolivet

yves.jolivet@univ-lorraine.fr

Matthieu Bagard

matthieu.bagard@u-pec.fr

Mireille Cabané

mireille.cabane@univ-lorraine.fr

Marie-Noëlle Vaultier

marie-noelle.vaultier@univ-lorraine.fr

Anthony Gandin

anthony.gandin@univ-lorraine.fr

Dany Afif

dany.afif@univ-lorraine.fr
- Aims This paper focuses on the negative impacts of ozone on trees in controlled conditions or in their natural environment. The current knowledge of the responses at cell level is presented and ways to improve their use for ozone risk assessment of forest stands are discussed.

- Methods Information was collected from original papers or reviews, providing an overview of the research conducted over the last 60 years.

- Results The negative effects of ozone on carbon assimilation and tree biomass production were reviewed and discussed, with a focus on effects on cell processes implied in cell defence, including stomatal regulation, detoxification, signalling, and biosynthesis of wood compound.

- Conclusion In the context of increasing significance of $\mathrm{O}_{3}$ flux approach, this review intends to shed light into the black box of defence processes, which are playing a crucial part within the effective $\mathrm{O}_{3}$ dose modelling. Today, it is recognized that tropospheric ozone inhibits tree growth and its role on the future carbon sink of the forest ecosystem is discussed along with the combination of other environmental factors like elevated temperature,

Pierre Dizengremel

pierre.dizengremel@univ-lorraine.fr

Didier Le Thiec

lethiec@nancy.inra.fr

1 Université de Lorraine, UMR 1137, Ecologie et Ecophysiologie Forestières, BP 70239, 54506 Vandoeuvre-lès-Nancy Cedex, France

2 INRA, UMR 1137, Ecologie et Ecophysiologie Forestières, F-54280 Champenoux, France

3 Institut d'Ecologie et des Sciences de l'Environnement de Paris, UMR7618, Université Paris Est Créteil, 61 avenue du Général De Gaulle, F-94010 Créteil Cedex, France 
water, and nitrogen supply, likely to be modified in the context of climate change.

Keywords Ozone impact · Defence - Carbon assimilation . Carbonallocation $\cdot$ Stomata $\cdot$ Detoxification $\cdot$ Signalling $\cdot$ Cell wall

\section{Introduction}

As a result of human activities, Earth climate is assumed to change (IPCC 2013) as we enter a new geologic era, the Anthropocene (Barnosky et al. 2012; Steffen et al. 2011). It is now well established that the release of greenhouse gases (GHGs) affects climate on a global scale, since these gases modify radiative transfer and thus change the Earth's energy balance (IPCC 2013). Tropospheric ozone $\left(\mathrm{O}_{3}\right)$, one of these GHGs and an important component of air pollution, is predicted to spread over large parts of the globe in the coming decades (Dentener et al. 2005; Fig. 1). In addition, this pollutant is thought to impact negatively forest productivity (Ainsworth et al. 2012), although species composition can modulate this effect (Wang et al. 2016). Since a large part of global forest areas is predicted to be exposed to $\mathrm{O}_{3}$ in the future (Fowler et al. 1999), carbon sequestration by forests may be reduced (Sitch et al. 2007; Subramanian et al. 2015). Historically, the phytotoxic effect of photooxidants, including $\mathrm{O}_{3}$, was first discovered in the 1950s in mixed conifer forests from the Los Angeles basin (Haagen-Smit et al. 1952). High concentrations of tropospheric $\mathrm{O}_{3}$ are an urban problem linked to car traffic and $\mathrm{NO}_{x}$ formation, but $\mathrm{O}_{3}$ or its precursors are easily airborne and the pollutant can damage forest trees far from the source of emission. In the 1980s, several research groups showed that visible symptoms of injury on tree leaves in different regions of the USA were clearly related to the effect of photooxidants (Miller et al. 1997; Skelly et al. 1997). In Europe, in the middle of the 1980s, the German foresters were the first to draw attention to visible damages observed on coniferous trees, incriminating air pollution (Krause et al. 1986). The same observation was also made in Eastern France, leading to the development of a bilateral cooperation for exploring the causes of this problem between the French DEFORPA programme (1984-1991) and the German partners, followed with the common EUREKA programme EUROSILVA (1992-1994). In the 1990s, extended European cooperation (eight countries) started on the effects of groundlevel $\mathrm{O}_{3}$ on trees and on the reduction of air pollutants, linked to the European Framework Programme for Research (e.g. STEP) and within the United Nations Economic Commission for Europe (UNECE).

The first experiments operated by these research programmes were conducted on trees in the field, e.g. in Germany (Weidmann et al. 1990) and in Austria (Wieser and Havranek 1993). Subsequently, experiments in controlled conditions (open-top chambers and phytotronic chambers) were set up to decipher the mechanisms of $\mathrm{O}_{3}$ impact on leaves of young trees (Gerosa et al. 2009; Sandermann et al. 1997). The trees display a series of defence responses to $\mathrm{O}_{3}$ which, when overwhelmed, leads to different types of damages including leaf necrosis and growth reduction. The obtained results proved that, before visible symptoms appear, $\mathrm{O}_{3}$ affects the leaf metabolism by damaging the photosynthetic machinery and by increasing carbon use, further
Fig. 1 Predicted differences in decadal averaged surface $\mathrm{O}_{3}$ concentrations (ppbv) comparing the 2020s and the 1990s for two global chemistry-transport models (from Dentener et al. 2005). a TM3 CLE Eulerian global chemistry-transport model using the current legislation (CLE) scenario; b STOCHEM CLE Lagrangian tropospheric chemistry-transport model using the current legislation (CLE) scenario

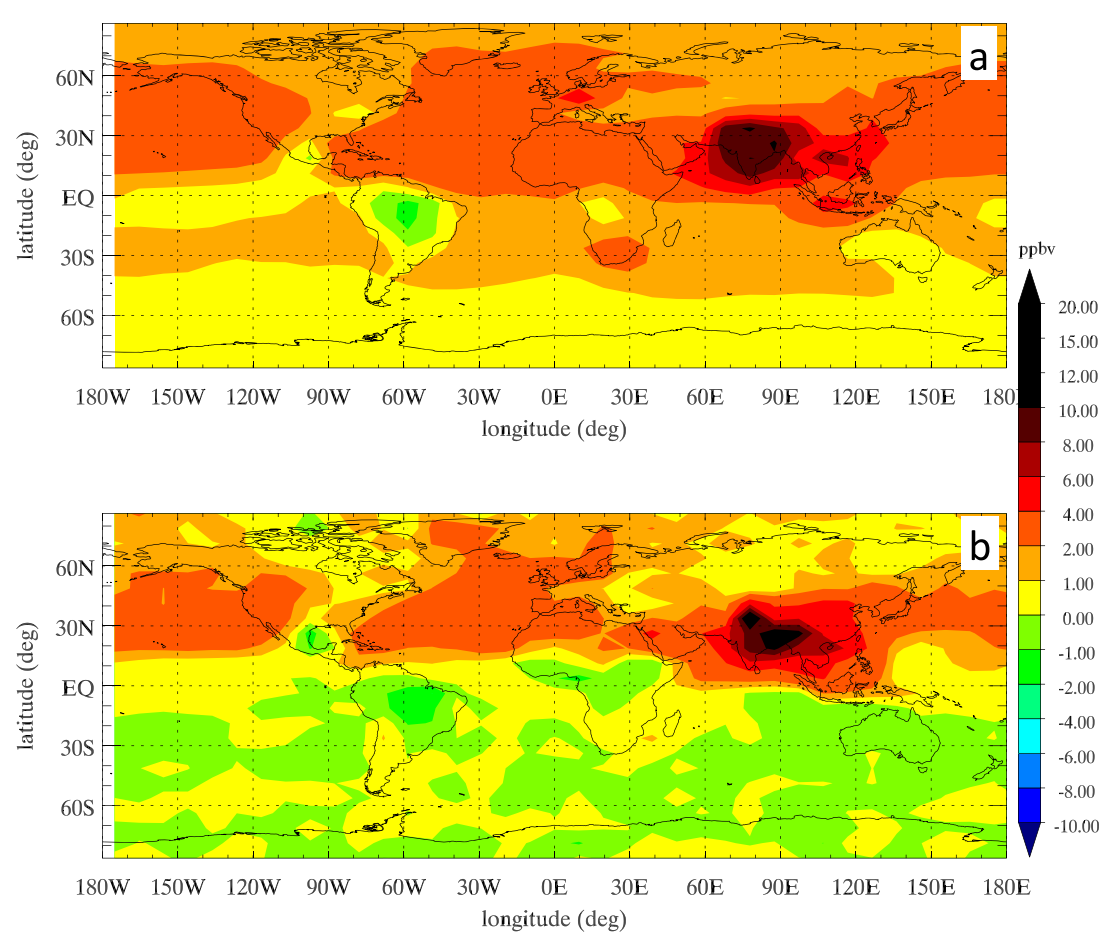


leading to reduced growth and productivity (Dizengremel 2001; Heath and Taylor 1997). The development of free-air $\mathrm{CO}_{2}$ enrichment (FACE) projects provided a nice opportunity to study forest ecosystem responses to the increase of tropospheric $\mathrm{O}_{3}$ combined or not with high $\mathrm{CO}_{2}$ exposure (King et al. 2005). The gap between the two approaches (field versus controlled conditions) has recently been partly reduced through the German CASIROZ programme by developing a large set of ecophysiological and biochemical analyses on mature beech and spruce trees submitted to free-air $\mathrm{O}_{3}$ fumigation (Matyssek et al. 2010b), on birches in Finland (Oksanen et al. 2007) and on conifers in Austria (Wieser et al. 2013). However, the degree of sensitivity to ozone is highly variable between tree species (Reich 1987; Wittig et al. 2009), raising the question of the underlying physiological processes (Matyssek et al. 2012).

In 2000 , to meet the request from policy makers to the scientific community for quantitative information about $\mathrm{O}_{3}$ effects, a specific European programme for the assessment, validation and mapping of visible $\mathrm{O}_{3}$ injury on the vegetation was set up, based on the ICP Forests monitoring network. The concept of a critical level for $\mathrm{O}_{3}$, introduced by UNECE (LRTAP convention 2004), was originally based on the accumulated exposure over a threshold concentration of $40 \mathrm{ppb}$ (AOT40). For forest trees, exceeding an AOT40 value of $5 \mathrm{ppm} . \mathrm{h}$ accumulated over one growing season would cause growth reduction (LRTAP convention 2004). More recently, a flux-based concept was developed in order to take into account the actual $\mathrm{O}_{3}$ flux in the leaf through the stomata (Emberson et al. 2000; Grünhage et al. 2004; Karlsson et al. 2004). Indicators such as AFstY (accumulated stomatal flux above a threshold of $Y$ nmol m$~^{-2} \mathrm{~s}^{-1}$ ) or POD $_{\mathrm{Y}}$ (phytotoxic ozone dose above a threshold flux of $Y$ nmol m ${ }^{-2} \mathrm{~s}^{-1}$ ) appear more representative of the impact of $\mathrm{O}_{3}$ on vegetation as, being based on the Jarvis multiplicative model of stomatal conductance (Jarvis 1976), they take into account temperature, water vapor pressure deficit (VPD), light, soil water potential, concentration of $\mathrm{O}_{3}$ and the plant phenology. These indices simulate the uptake of $\mathrm{O}_{3}$ in leaves and represent the hourly average flux accumulated above a threshold $Y$ by a leaf during the plant growth. Hoshika et al. (2014) also proposed to take into account a stomatal $\mathrm{O}_{3}$ flux per net photosynthesis rate rather than stomatal $\mathrm{O}_{3}$ flux only. All these flux-based methodologies rely on empirically derived relationships, linking stomatal $\mathrm{O}_{3}$ flux to tree biomass loss through a series of models at leaf, tree and forest levels. These relationships thus provide estimates of the effective $\mathrm{O}_{3}$ dose, i.e. the fraction of $\mathrm{O}_{3}$ flux exceeding the plant detoxification capacity, under consideration of the environmental conditions (Matyssek et al. 2004; Musselmann et al. 2006; Dizengremel et al. 2008; Heath et al. 2009; Buker et al. 2015). The importance of the detoxification capacity of the tree was recently emphasized (de Temmerman et al. 2002; Dizengremel et al. 2013; Dizengremel et al. 2008) and was previously raised to explain the differences in $\mathrm{O}_{3}$ sensitivity of tree species (Pell et al. 1999). Detoxification capacity depends on a network of molecular and physiological processes which needs to be deciphered in order to identify a reliable parameter, integrated in models and allowing a more accurate risk assessment. In brief, the integration in field models of a pertinent ozonedamaging factor, identified at the cellular level, could improve risk assessment and help policy makers with related socioeconomic decisions.

Since 60 years, $\mathrm{O}_{3}$ research has covered a large spectrum of interest, including detailed studies of the cellular events induced by acute doses. In this review, acute doses correspond to observed peak concentrations with values above $120 \mathrm{ppb}$ for several days, while chronic exposure refers to long-term exposures (weeks, months, years) to ozone concentrations below $120 \mathrm{ppb}$. The increasing interest to study the effects of this gas is partly due to the fact that the exposure to high $\mathrm{O}_{3}$ concentrations elicits a strong oxidative stress at the tissue level. Moreover, with hourly peak $\mathrm{O}_{3}$ concentrations at periurban regions reaching 200 ppb (Feng et al. 2014), acute conditions are de facto validated in natural conditions inducing serious damage to plants. $\mathrm{O}_{3}$ research has also known a progressive extent in the study of chronic exposure with values not higher than $100 \mathrm{ppb}$ over the growth period. However, experiments in controlled conditions with slightly higher $\mathrm{O}_{3}$ exposure (up to $120 \mathrm{ppb}$ ) applied every day during a shorter time (no more longer than 3 weeks/1 month) were also frequently used to mimic the effect of these ambient long-lasting $\mathrm{O}_{3}$ exposures. Even though the increase in tropospheric $\mathrm{O}_{3}$ concentrations has recently flattened in mid-latitudes of the Northern Hemisphere (Oltmans et al. 2013), assessing the effects of $\mathrm{O}_{3}$ on forest trees remains a timely question considering that the threshold for a negative impact on growth has been already reached. In this context, we present a survey of works on the effects of this oxidative pollutant in a relative short term on tree physiology (Fig. 2). These information are necessary to extrapolate on a longer term the $\mathrm{O}_{3}$ effect at the forest ecosystem scale, which have also to integrate with the complex inter-relationships among the environmental factors occurring over the life span of a tree.

\section{Formation, transport, deposition of $\mathrm{O}_{3}$, and leaf damage}

\subsection{Formation}

In the troposphere, under the action of sunlight, primary pollutants like nitrogen oxides and hydrocarbons are able to form photochemical air pollutants, referred to as secondary pollutants, namely peroxyacetyl nitrate (PAN), $\mathrm{O}_{3}$ and to a lower extent aldehydes and ketones (Becker et al. 1985). The future of PAN is closely related to atmospheric 
Fig. 2 Overview of $\mathrm{O}_{3}$ effects on trees, from cell metabolism to forest ecosystem scale, highlighting (i) the perception of the pollutant at the leaf scale, (ii) the cellular responses implying detoxification and $\mathrm{CO}_{2}$ assimilation and (iii) the carbon allocation to the various plant organs and the consequences on tree growth and on carbon sequestration at the forest level. Where arrows are present, red and blue indicate an $\mathrm{O}_{3}$-driven inhibition and stimulation, respectively. BVOCs biogenic VOCs

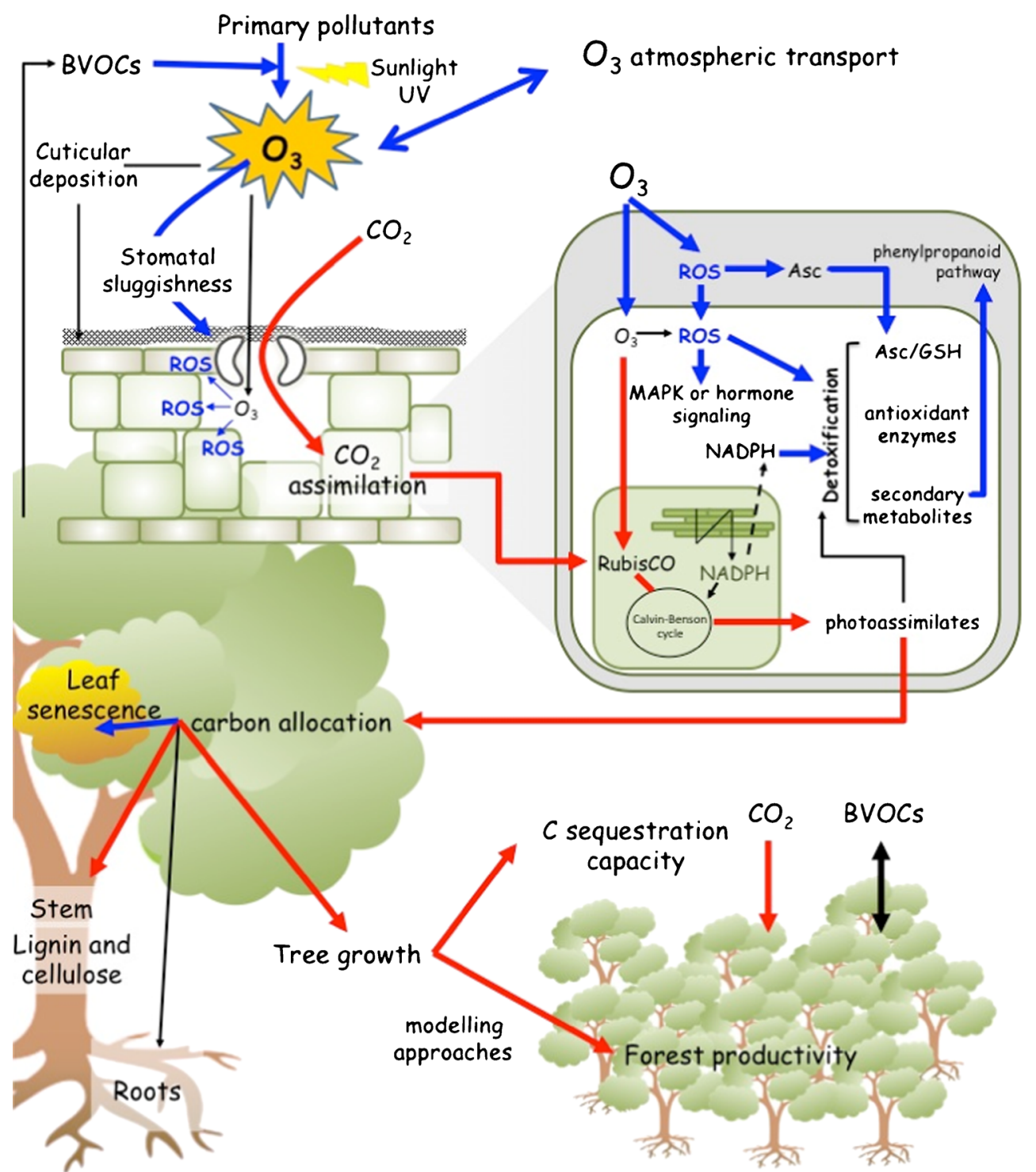

temperatures and could contribute to $\mathrm{O}_{3}$ formation in the warmer lower atmosphere (Singh 1987). The presence of $\mathrm{O}_{3}$ in the troposphere was initially considered as the result of a stratospheric $\mathrm{O}_{3}$ transfer, which only accounts for up to $25 \%$ of tropospheric $\mathrm{O}_{3}$ (LRTAP convention 2010). In fact, $\mathrm{O}_{3}$ formation mainly results from complex processes already detailed in several reviews (Becker et al. 1985; Royal Society 2008; Stockwell et al. 1997). Briefly, once nitrogen dioxide $\left(\mathrm{NO}_{2}\right)$ is formed, it endures a photodissociation caused by short radiations (between 280 and $430 \mathrm{~nm}$ ) producing nitrogen monoxide (NO) and free oxygen atoms. The free oxygen atom presents a high excitation level leading to a reaction with $\mathrm{O}_{2}$ to form $\mathrm{O}_{3}$. The subsequent reaction of $\mathrm{O}_{3}$ with $\mathrm{NO}$ can lead to the destruction of $\mathrm{O}_{3}$ in a nonpolluted area, where the $\mathrm{NO}_{2} / \mathrm{NO}$ ratio is low. However, one parameter susceptible to unbalance these reactions is the presence of volatile organic compounds (VOCs) including $\mathrm{CH}_{4}$ (Royal Society 2008). VOCs are able to oxidize
$\mathrm{NO}$, increasing the $\mathrm{NO}_{2} / \mathrm{NO}$ ratio and shifting the reactions towards $\mathrm{O}_{3}$ accumulation. Finally, the production of $\mathrm{O}_{3}$ in the troposphere is linked to changing precursor concentrations, a relationship that highlights the non-linearity of the $\mathrm{O}_{3}$-VOC-NO $\mathrm{N}_{x}$ system (Monks et al. 2015). Vegetation and particularly forests are natural VOC producers (Sharkey et al. 2008). In a context of warming climate, VOC emissions are projected to increase and to contribute to the occurrence of $\mathrm{O}_{3}$ peaks or the increase of the tropospheric $\mathrm{O}_{3}$ background level. Finally, the photolysis of $\mathrm{O}_{3}$ leads to additional radicals that can react with carbon monoxide and organic species, leading to additional $\mathrm{O}_{3}$ production (Royal Society 2008).

\subsection{Transport of the pollutants in the troposphere}

Most of air pollutant emissions, including $\mathrm{O}_{3}$ precursors, originate from regions within the mid-latitudes, where long-range

\section{Q Springer}


transport of air masses is dominated by westerly winds. These winds convey emissions from source regions to downwind regions at interregional and even intercontinental scales (Stohl and Eckhardt 2004). The lifetime of $\mathrm{O}_{3}$ in the free troposphere varies from weeks to months, which is compatible with long-range transport that occurs on timescales of days to weeks (LRTAP convention 2010). Due to the stronger winds at high altitudes, $\mathrm{O}_{3}$ formed or transported into the mid- and upper troposphere travels further and faster than $\mathrm{O}_{3}$ remaining in the lower troposphere, below $3 \mathrm{~km}$ in altitude (LRTAP convention 2010). $\mathrm{O}_{3}$ formation can also occur at distance from precursor source regions, when polluted air masses arrive at a downwind region and meet conditions that promote $\mathrm{O}_{3}$ formation (Lin et al. 2012).

When confined within the atmospheric boundary layer, $\mathrm{O}_{3}$ has a relatively short lifetime (hours to days) due to dry deposition at terrestrial surfaces (Wesely and Hicks 2000). Dry deposition occurs when $\mathrm{O}_{3}$ is taken up or absorbed onto surfaces (vegetation, soil, materials) that provide a chemical sink for $\mathrm{O}_{3}$ decomposition (Cape et al. 2009). Surface removal represents an important control on the near-surface $\mathrm{O}_{3}$ concentrations and constitutes a major term in the global mass balance of tropospheric $\mathrm{O}_{3}$ (Fowler et al. 2009). While molecular processes become important very close to surfaces (less than $1 \mathrm{~mm}$ ), turbulent transfer represents the main driver of gas exchange between vegetation and the atmosphere. Forests being aerodynamically rough surfaces, the rates of turbulent exchange between the atmosphere and forests exceed by an order of magnitude or more those over crops or grasslands (Fowler et al. 1999). As a consequence, forests represent a major sink for $\mathrm{O}_{3}$ dry deposition.

\section{$2.3 \mathrm{O}_{3}$ deposition to soil and vegetation}

The foliage of forest trees acts as the dominant $\mathrm{O}_{3}$ sink in the atmosphere-forest interaction, and the canopy structure has a noticeable effect on its uptake (Zhang et al. 2006). Forest ecosystems have the capacity to remove $\mathrm{O}_{3}$, through both stomatal and non-stomatal mechanisms (Fig. 2) (Dizengremel et al. 2013; Fares et al. 2013b). The stomata are the main entry point of ozone into the leaves, and the non-stomatal mechanisms of ozone deposition include cuticular deposition, deposition at the soil surface and destruction by chemical reactions $\left(\mathrm{NO}_{x}\right.$, biogenic VOC). Most studies of vertical $\mathrm{O}_{3}$ concentration gradients show that only minor variations occur throughout forest canopies during daytime, mainly due to convective mixing caused by solar radiation (Jaggi et al. 2006). Overall, during daytime, the $\mathrm{O}_{3}$ concentrations below the canopy of various forest types are 0 to $15 \%$ lower than those measured at the top of the canopy (Andreae et al. 2002; Fontan et al. 1992; Joss and Graber 1996). However, stronger gradients appear at night because of a greater air stability, which limits the exchange between the canopy and the atmosphere above, and due to radiative cooling inducing strong temperature inversions near the ground (Skelly et al. 1996). As a consequence, the $\mathrm{O}_{3}$ concentrations near the forest floor are lower than those measured in the canopy or in the atmosphere above, especially at night (Fontan et al. 1992). By combining $\mathrm{O}_{3}$ concentration measurements and stomatal conductance estimations, it is possible to get a rather good knowledge of the dose absorbed by the plant. However, the determination of the $\mathrm{O}_{3}$ stomatal conductance is far from trivial. Whatever the method used, the values are subject to uncertainties. Many measurements and modelling studies of $\mathrm{O}_{3}$ flux for various canopies and different seasons exist (Massman 2004; Padro 1996; Wesely and Hicks 2000). However, there are still large doubts concerning the processes controlling $\mathrm{O}_{3}$ deposition to plant surfaces (Ashmore et al. 2007), and therefore in the partitioning of the $\mathrm{O}_{3}$ flux between stomatal and non-stomatal uptakes, whose relative contributions vary with canopy type and with the season of the year (Tuovinen et al. 2009; Zhang et al. 2006). Many studies have been dedicated to this question, and most of them show an enhancement of $\mathrm{O}_{3}$ deposition with increased surface wetness.

Significant (20-80\% of total) non-stomatal $\mathrm{O}_{3}$ fluxes have been observed in different forests in southern European conditions (Cieslik 2009), which often limit the gas flux through stomata. A 10-year-long measurement in a boreal Scots pine forest in Finland showed that the non-stomatal $\mathrm{O}_{3}$ deposition in the daytime during the growing season varied within 26 $44 \%$ of total deposition (Rannik et al. 2012). Another decadelong dataset collected in a mixed temperate forest in Belgium showed larger non-stomatal fractions, exceeding $60 \%$ even during the daytime in summer (Neirynck et al. 2012).

The correct quantification of the different components of the deposition, including the stomatal fraction, is also required when assessing the possible feedbacks between $\mathrm{O}_{3}$ uptake rates and plant injury or damage, photosynthesis and plant defences. Scaling functional processes of forest trees from leaves and compartments (soil, canopy) to stands, ecosystems and, finally, the landscape level (Wieser et al. 2008) is fundamental for understanding the capacity of forest ecosystems to mitigate air pollution effects and to adapt to changing environmental conditions (Matyssek et al. 2012).

\subsection{Leaf damage}

As a strong oxidant, $\mathrm{O}_{3}$ causes several types of visible injury, including chlorosis and necrosis (http://hermes.wsl. $\mathrm{ch} /$ didado/ozoniwww.page0?sprache=E). These symptoms, well characterized in controlled conditions, could be also observed on leaf trees in rural areas and mountains, downwind from cities (Dalstein et al. 2002; Feng et al. 2014 ; Miller et al. 1994) or in forested areas exposed to ambient $\mathrm{O}_{3}$ concentrations high enough to produce phytotoxic effects (de Vries et al. 2014). In this latter case, it is obvious that the 
interpretation is more doubtful, conditioned by the complex interactions between $\mathrm{O}_{3}$ and environmental factors inside the canopy of adult trees or linked to water and mineral availability of the soil (Bussotti and Ferretti 2009; Manning 2005). $\mathrm{O}_{3}$ can also induce an accelerated senescence and leaf abscission (Gielen et al. 2007; Karnosky et al. 2005; Ribas et al. 2005). Finally, although visible symptoms can be useful for detecting an $\mathrm{O}_{3}$ impact, their relationship with growth reduction is not always found (de Vries et al. 2014).

\section{Cellular and molecular mechanisms impacted by $\mathrm{O}_{3}$}

\subsection{Impact on guard cells}

Ainsworth et al. (2012) reported that a reduction in stomatal conductance in plants exposed to chronic elevated $\mathrm{O}_{3}$ (range to $80-120 \mathrm{ppb}$ ) could be attributed to a direct effect of $\mathrm{O}_{3}$ on photosynthesis and to a resultant increase in internal $\mathrm{CO}_{2}$ concentration. However, alternative reactions might explain this response (Pell et al. 1992). In fact, studies reported that stomata are impaired by chronic $\mathrm{O}_{3}$ exposure in their ability to close rapidly in response to environmental stimuli (McAinsh et al. 2002; Reich et al. 1984). More recently, it was shown that stomata open and close more slowly in response to changing light conditions, VPD or $\mathrm{CO}_{2}$ concentrations as a result of $120 \mathrm{ppb} \mathrm{O}_{3}$ exposure (Dumont et al. 2013) or with 1.5- to 2fold $\mathrm{O}_{3}$ ambient level (Paoletti 2005; Paoletti and Grulke 2010). Some molecular aspects were studied in order to explain how $\mathrm{O}_{3}$ modifies the signals involved in opening or closure processes (Vahisalu et al. 2010). Dumont et al. (2014) showed on poplar genotypes that modification of stomatal responses by an exposure to $120 \mathrm{ppb}$ of $\mathrm{O}_{3}$, such as stomatal sluggishness (Fig. 2), does not result from ultrastructural changes but from a disturbance of ion fluxes and a regulation of the gene expression involved in signal transduction. The expression of a majority of the studied genes coding for plasma membrane and vacuolar channels was inhibited by $\mathrm{O}_{3}$, especially the expression of genes coding for the plasma membrane proton ATPase (AHA11) and the vacuolar calcium channels (CAX1 and CAX3) (Dumont et al. 2014).

There is also more recent evidence that stomatal conductance is not universally reduced by elevated $\mathrm{O}_{3}$ concentration, but that leaf age and tree developmental stage can alter the degree to which $\mathrm{O}_{3}$ affects stomatal conductance (Uddling et al. 2009). Danielsson et al. (2003) and Pleijel et al. (2002) added the effect of $\mathrm{O}_{3}$ to the phenology function (related to the reduction of the stomatal conductance in senescing leaves) of the stomatal conductance model in potato and wheat. That new function is being increasingly used, but more knowledge is needed to determine if the effects of $\mathrm{O} 3$ on trees should really be integrated in the same way as to link the $\mathrm{O} 3$ function to another function than phenology function so far. Further research is needed (i) to characterize $\mathrm{O}_{3}$ impacts on stomatal function as well as the interaction with other abiotic stresses like drought and (ii) to improve stomatal conductance models like the DO3SE model (Büker et al. 2012). In these models, we need to improve the estimation of the start and end of the growing season today and in the future.

\subsection{Detoxification}

Once $\mathrm{O}_{3}$ enters the sub-stomatal chamber, it rapidly induces the formation of reactive oxygen species (ROS) like hydrogen peroxide, singlet oxygen and hydroxyl radicals, increasing the oxidative load to the apoplastic fluid (Fig. 2). The primary effect of ROS is the alteration of membrane and enzyme proteins, e.g. Rubisco (Dizengremel 2001; Heath 2008; Pell et al. 1992). The ability to limit the occurrence of ROS in the apoplast could confer the $\mathrm{O}_{3}$ tolerance of aspen clones (Oksanen et al. 2004). Apoplastic ascorbate (Asc) is considered as the first line of defence against $\mathrm{O}_{3}$, as observed in herbaceous plants (Conklin and Barth 2004) but also in beech (Haberer et al. 2007; Luwe and Heber 1995), silver birch (Padu et al. 2005) or spruce and pine needles (Polle et al. 1995). However, the Asc levels in the apoplast are not sufficient to explain the different degrees of $\mathrm{O}_{3}$ sensitivity in poplar clones (Ranieri et al. 1999). The lack of any direct relation between species sensitivity and apoplastic Asc levels was attributed (i) to the high level of Asc oxidation in this compartment, (ii) to its low concentration relative to the total cell content and (iii) to the occurrence of other antioxidants (Castagna and Ranieri 2009; Dizengremel et al. 2013).

At the whole-leaf level, changes in Asc content increased or decreased according to the exposure level and the duration of $\mathrm{O}_{3}$ treatment, the leaf age, the growth stage or the position of the leaf in the canopy (Haberer et al. 2007; Strohm et al. 2002; Tausz et al. 2004; Wellburn et al. 1996). Thus, the higher $\mathrm{O}_{3}$ sensitivity of young beech in phytotrons compared to adult forest trees in the field has been partly attributed to differences in detoxification capacity and notably total ascorbate concentration (Nunn et al. 2005). From a series of studies conducted on poplar exposed to $\mathrm{O}_{3}$ in controlled conditions or in the field, it is difficult to establish a clear relation between the constitutive level of Asc and the genotype sensitivity (Di Baccio et al. 2008; Dumont et al. 2014; Yun and Laurence 1999). However, a higher level of dehydroascorbate (DHA) in a sensitive poplar genotype (Dumont et al. 2014) exposed to $120 \mathrm{ppb} \mathrm{O_{3 }}$ may express a lower capacity of the genotype to regenerate the reduced form (AsA), a hypothesis supported by a lower NADPH content in the leaves of this genotype (Dghim et al. 2013a).

In the absence of glutathione in the apoplasm, the Asc regeneration process implies the transport of DHA in the 
cytosol followed by the functioning of the intra-cellular ascorbate-glutathione cycle (Noctor 2006). This cycle sustains AsA regeneration in the cytosol. Glutathione is known as an antioxidant, able to directly react with ROS, sometimes functioning in a compensatory manner to Asc but also with specific functions (Noctor et al. 2012). Total glutathione and/or reduced glutathione content generally increased in leaves of tree species under $\mathrm{O}_{3}$ fumigation (100 to $120 \mathrm{ppb}$ ) (Dumont et al. 2014; Wellburn et al. 1996). In adult beech trees, the glutathione level is affected by canopy position, but $\mathrm{O}_{3}$ exposure (twofold ambient concentration) involved higher content in both shade and sun leaves (Herbinger et al. 2005). In some works, the differences in the constitutive levels of glutathione between poplar genotypes appeared to contribute to the higher tolerance to chronic $\mathrm{O}_{3}$ exposure (Di Baccio et al. 2008; Dumont et al. 2014). However, attempts to increase glutathione content and glutathione reductase activity in transgenic poplar were unsuccessful in increasing tolerance, at least to acute (300 ppb) $\mathrm{O}_{3}$ exposure (Strohm et al. 2002).

Phenolic compounds are also recognized in leaf like important metabolites to cope with elevated or chronic $\mathrm{O}_{3}$ exposure of trees (Fares et al. 2010; Kontunen-Soppela et al. 2007; Peltonen et al. 2005; Yamaji et al. 2003). For some phenolics and condensed tannins, a potential role in the $\mathrm{O}_{3}$ tolerance has been claimed (Haikio et al. 2009; Kontunen-Soppela et al. 2007). Furthermore, in accordance with an increased level in phenolics, the induction of the shikimate and phenylpropanoid pathways shared by the flavonoid, anthocyanin, tannin, stilbene and lignin biosynthesis has been well documented under $\mathrm{O}_{3}$ exposure (see Cabané et al. 2012 for review). For some tree species that emit large amounts of VOCs, it is also interesting to consider the potential role of these compounds like antioxidants, as found for isoprene in poplar (Loreto et al. 2001) and for monoterpenes in oak (Loreto et al. 2004). However, recent works on poplar showed that the relationship between $\mathrm{O}_{3}$ tolerance and the ability to emit isoprene is not so clear (Behnke et al. 2009; Calfapietra et al. 2008). The involvement of polyamines like radical scavengers and protectant against $\mathrm{O}_{3}$ has been also considered although these studies are limited (Ludwikow and Sadowski 2008).

In addition to metabolites, a large panel of antioxidant enzymes are involved in the defence mechanisms to decrease the ROS level or to regenerate the reduced form of some antioxidants (Fig. 2). Firstly, extracellular enzymes like superoxide dismutases (SOD) and peroxidases (with ascorbate or phenolics as preferential electron donors) were identified as significant contributors to the mitigation of ROS generation in the apoplasm of birch (Padu et al. 2005) and poplar leaves (Castagna and Ranieri 2009). When the apoplastic antioxidant capacity is overwhelmed, other isoforms of these enzymes were implied to limit the generation of cytoplasmic ROS. Thus, total SOD and/or peroxidase activities generally increased in $\mathrm{O}_{3}$-treated leaves of trees (Bernardi et al. 2004;
Diara et al. 2005; Sehmer et al. 1998; Tuomainen et al. 1996) even though conflicting results have been mentioned (Heath and Taylor 1997). It has been claimed that the different affinities for ROS of the antioxidant enzymes either may be linked to the regulation of ROS as signalling actors or may be responsible for the removal of excess ROS (Mittler 2002). More generally, maintaining a cellular steady state of the ROS in responses to stresses is assigned to a complex enzyme network with actors like thioredoxin-dependent peroxidases (including peroxiredoxins and glutathione peroxidase), glutaredoxins and glutathione-S transferases (Foyer and Noctor 2011; Mittler et al. 2004; Rouhier and Jacquot 2005). Hence, the regulation of the enzymatic antioxidant system involves a fine redox regulation (Jacquot et al. 2013). For some of these enzymes, their characterization in trees (mainly poplar) is recent (Navrot et al. 2006; Rouhier 2010) but their regulation under $\mathrm{O}_{3}$ or other oxidative pollutants is still undefined. Moreover, in these stress conditions, the source of reducing power to supply some of the ROS-scavenging systems remains to be elucidated (Dghim et al. 2013b; Dizengremel et al. 2008). Finally, to propose a new index for $\mathrm{O}_{3}$ risk assessment integrating the plant detoxification capacity, a complex network of metabolites and enzymes has to be taken into account. But for trees, the variations of these parameters along the successive growing seasons as well as the canopy position must also be considered.

\subsection{Carbon assimilation and leaf senescence}

One of the first $\mathrm{O}_{3}$-driven decreases in growth was characterized by Reich (1983) in greenhouse-grown trees and directly correlated to a reduction in net $\mathrm{CO}_{2}$ assimilation rate (Fig. 2). This correlation was then confirmed in fumigation chamber, open-top chamber and field fumigation systems across several tree species (Reich 1987). In a meta-analytic review, Wittig et al. (2007) showed that the $\mathrm{O}_{3}$-driven decrease in carbon assimilation reached $14 \%$ for angiosperm trees grown in ambient background $\mathrm{O}_{3}$ relative to charcoalfiltered air. Differently, gymnosperms were not significantly affected. However when exposed to severe $\mathrm{O}_{3}$ concentration (85 ppb), net $\mathrm{CO}_{2}$ assimilation was similarly decreased (up to $19 \%$ ) in both angiosperms and gymnosperms. The average decrease in $\mathrm{CO}_{2}$ assimilation was progressively greater as the $\mathrm{O}_{3}$ treatment increased (Wittig et al. 2007). $\mathrm{O}_{3}$ impact on photosynthesis could be threshold dependent, highlighting the importance to better define critical $\mathrm{O}_{3}$ threshold across species and/or environmental conditions. Differences in photosynthesis response to $\mathrm{O}_{3}$ may partly be explained by interspecific variability of stomatal response to $\mathrm{O}_{3}$ and therefore gas flux entering the leaf. Over hundreds of individuals indicate an $11 \%$ and $13 \%$ decrease in average in $\mathrm{CO}_{2}$ uptake and stomatal conductance, respectively (Wittig et al. 2007). Stomatal limitation under $\mathrm{O}_{3}$ may in part explain 
the reduced photosynthetic $\mathrm{CO}_{2}$ uptake in restricting $\mathrm{CO}_{2}$ diffusion from the atmosphere to the intercellular space and therefore $\mathrm{CO}_{2}$ availability at the site of carbon fixation (see section on stomatal regulation above).

In addition, $\mathrm{O}_{3}$ has been widely shown to affect both the Calvin-Benson cycle and photochemistry activity (Fig. 2) (Saxe 2002). A decrease in Rubisco activity and content was strongly correlated with cumulative $\mathrm{O}_{3}$ exposure in loblolly pine (Dizengremel et al. 1994). Similarly, in Aleppo pine, both Rubisco and Rubisco activase levels were reduced under $\mathrm{O}_{3}$ (Pelloux et al. 2001). In angiosperms also, multiple works supported the idea of $\mathrm{O}_{3}$-driven alteration of Rubisco activity (Gaucher et al. 2003; Lutz et al. 2000; Matyssek et al. 1991; Pell et al. 1992). However, it remains unclear whether the decrease in Rubisco activity is due to enhanced degradation, ROS-mediated protein oxidation, decreased Rubisco activase activity or altered gene expression (Brendley and Pell 1998; Dizengremel 2001; Heath 2008; Pell et al. 1994). It is well documented that chronic as well as acute $\mathrm{O}_{3}$ exposures impact gene regulation (Ernst 2013; Renaut et al. 2009) even though acute episodes could provoke more important changes than chronic ones (Ainsworth et al. 2012; Ernst 2013). Furthermore, proteomic analysis confirms the downregulation of a large number of proteins involved in the Calvin-Benson cycle in poplar leaves exposed to chronic $\mathrm{O}_{3}$, as well as proteins involved in chloroplastic electron transport (Bohler et al. 2007). $\mathrm{O}_{3}$ also decreases chloroplast size and cell starch content (Oksanen et al. 2004). Chlorophyll and carotenoid levels have been shown to decrease under $\mathrm{O}_{3}$, resulting likely in a less active photochemistry and a slower electron transport rate (Bagard et al. 2008). It is, however, unclear whether the slower electron transport rate under $\mathrm{O}_{3}$ is due to a lower leaf pigment level or a downregulation of PSII activity in order to avoid photooxidative damage. In addition, photochemistry can also be diminished under a long-lasting reduction of stomatal conductance. Such electron transport slowdown would likely limit $\mathrm{NAD}(\mathrm{P}) \mathrm{H}$ production and availability for anabolic process, detoxification and photosynthetate synthesis. The drastic decrease in chlorophyll and Rubisco contents is correlated with accelerated leaf senescence (Miller et al. 1999). Genes involved in senescence and protein turnover are upregulated in Populus tremuloides leaves exposed to $\mathrm{O}_{3}$ (Gupta et al. 2005). Early senescence would restrict the "return on investment" in leaf buildup and therefore drastically affect plant carbon budget.

The reduced net $\mathrm{CO}_{2}$ assimilation in $\mathrm{O}_{3}$-exposed leaves is largely driven by a decrease in gross $\mathrm{CO}_{2}$ assimilation rate by the Rubisco, but it also results from increased $\mathrm{CO}_{2}$ losses through an enhanced respiration, as observed in poplar (Bagard et al. 2008; Noormets et al. 2001; Reich 1983), Norway spruce (Küppers and Klumpp 1988), Scots pine (Kellomaki and Wang 1998; Skärby et al. 1987), birch (Matyssek et al. 1997) and beech (Kitao et al. 2009). The increase in $\mathrm{CO}_{2}$ efflux from respiration is supported by an enhanced glycolysis, pentose-phosphate pathway and TCA cycle activity (Dizengremel 2001). A central enzyme linking these metabolic pathways, the phosphoenolpyruvate carboxylase, is strongly upregulated in $\mathrm{O}_{3}$-exposed leaves of a wide range of species (Dizengremel 2001; Dizengremel et al. 2012). PEPc activity produces oxaloacetic acid, a precursor for malate and pyruvate synthesis, and can therefore support the rising demand in organic acids for TCA cycle decarboxylation or anaplerotic pathways. PEPc-induced pathways could play a central role in $\mathrm{O}_{3}$ tolerance in providing additional carbon skeletons and $\mathrm{NAD}(\mathrm{P}) \mathrm{H}$ to detoxification processes (Dizengremel et al. 2009). Additionally, the increase in dark respiration under $\mathrm{O}_{3}$ is likely supported by a higher contribution of alternative pathways of the mitochondrial electron transport chain (Dizengremel 2001) that may be driven by a higher PEP content and subsequent higher pyruvate level (activator of alternative oxidase). The enhancement of the mitochondrial alternative electron transport would help to maintain a high respiratory rate in avoiding any respiratory control through oxidative phosphorylation and therefore contribute to reducing power availability for detoxification and repair of cellular damage (Dizengremel et al. 2009).

\subsection{Cell wall component biosynthesis in leaves and stems}

In addition to inducing a diverse range of defence responses, $\mathrm{O}_{3}$ has been shown to modify the cell wall. Anatomy analysis revealed thickened cell walls with pectinaceous projections in leaves of deciduous trees showing visible leaf symptoms (Gunthardt-Goerg et al. 1997; Gunthardt-Goerg et al. 2000). These observations suggested strong rearrangements in the cell wall organization and in its component biosynthesis in leaves of trees subjected to $\mathrm{O}_{3}$. However, most studies focused on one component, lignin.

$\mathrm{O}_{3}$ has been shown to stimulate phenylpropanoid metabolism in leaves of many tree species and under different fumigation protocols involving both acute and chronic exposure (Fig. 2). $\mathrm{O}_{3}$ increased both enzyme activities and related gene transcript levels involved in lignin biosynthesis in Pinus sylvestris (Rosemann and Heller 1991; Zinser et al. 1998), Picea abies (Galliano et al. 1993a; Galliano et al. 1993b; Heller et al. 1990), Populus spp. (Cabané et al. 2004; Di Baccio et al. 2008; Koch et al. 1998; Wustman et al. 2001), Betula pendula (Pääkkönen et al. 1998a; Tuomainen et al. 1996) and Fagus sylvatica (Jehnes et al. 2007; Olbrich et al. 2005). The responses of the phenylpropanoid metabolism can be both fast (Koch et al. 1998) and substantial (Cabané et al. 2004), and the induction levels were generally correlated with $\mathrm{O}_{3}$ concentrations (Cabané et al. 2004; Galliano et al. 1993b; Rosemann et al. 1991). Stimulation of the phenylpropanoid pathway was often maintained during the whole period of $\mathrm{O}_{3}$ exposure (Cabané et al. 2004; Galliano et al. 1993a) and could 
even continue after the end of the treatment (Tuomainen et al. 1996). Most of the above results were obtained from trees growing in controlled conditions or open-top chambers, and the same trend was also observed in more natural conditions such as free-air $\mathrm{O}_{3}$ fumigation facilities (Betz et al. 2009; Wustman et al. 2001). All these results unambiguously demonstrate that the phenylpropanoid pathway is upregulated in leaves under $\mathrm{O}_{3}$ exposure and is therefore probably involved in defence and acclimation mechanisms. As a consequence of the phenylpropanoid pathway stimulation, the lignin content must increase as a result of $\mathrm{O}_{3}$ exposure. Indeed, such results were found in leaves of sugar maple (Boerner and Rebbeck 1995), poplar (Cabané et al. 2004) and beech (Betz et al. 2009; Jehnes et al. 2007; Olbrich et al. 2010b). However, the effects of $\mathrm{O}_{3}$ fumigation on lignin content in leaves were not so clear. Thus, no modifications of lignin content were recorded in western yellow pine (Tingey et al. 1976), black cherry and yellow poplar (Boerner and Rebbeck 1995), loblolly pine (Booker et al. 1996), birch (Oksanen et al. 2005) and holm oak (Baldantoni et al. 2011). These varying results may be explained by potential error due to different techniques (Klason, LTGA, etc.) used to determine lignin content as well as their relative (in)sensitivity (Dence 1992), especially in the case of weak variations between control and treated samples. Another explanation could be species-specific differences in response to $\mathrm{O}_{3}$ treatment. For example, conifers never showed increased lignin content. Stimulation of the phenylpropanoid pathway could in such cases be associated with a modification of the pool of soluble phenolic and not necessarily lead to increased lignification (Tingey et al. 1976). Nevertheless, the newly synthesized lignin in leaves displayed changes in its structure (Betz et al. 2009; Cabané et al. 2004). Lignin was enriched in carbon-carbon interunit bonds and in H-units indicating the production of a more condensed lignin than usual. Moreover, lignified cells were observed in the mesophyll or epidermis near the necrotic lesions (Cabané et al. 2004) where ROS $\left(\mathrm{H}_{2} \mathrm{O}_{2}\right)$ were also shown to be accumulated (Pellinen et al. 2002). These results support the idea that stress lignins are synthesized in response to and in defence against $\mathrm{O}_{3}$ or ROS excess. Due to its scavenging properties, lignin may act as an antioxidant (Blokhina et al. 2003; Dizhbite et al. 2004).

Since the response to $\mathrm{O}_{3}$ has been extensively studied in leaves, few studies have analysed the $\mathrm{O}_{3}$ response of stems. This is understandable since leaves show clear $\mathrm{O}_{3}$-induced damage and a fast response while stems react much later (Richet et al. 2012). An increase in lignin content was observed in stems of poplar and birch fumigated for 3 years in a free-air fumigation experiment (Kaakinen et al. 2004), but this observation was not maintained after 5 years (Kostiainen et al. 2008). In a recent study, $\mathrm{O}_{3}$ was observed to repress the phenylpropanoid pathway in poplar wood (Richet et al. 2011), probably as a result of reduced cambial growth. However, the relative cell wall lignin content increased due to an $\mathrm{O}_{3}$ - induced reduction in cellulose biosynthesis, thereby modifying the cellulose to lignin ratio (Fig. 2). The stem response seems to correspond to a metabolic adjustment due to the reorientation of the metabolism to stress acclimation in leaves, rather than to a specific defence mechanism. $\mathrm{O}_{3}$ would not impact directly the stem organ (Richet et al. 2012). It was hypothesized that the modification of the cellulose to lignin ratio in the stem could allow the tree to maintain radial and height growth while minimizing carbon cost (Richet et al. 2011). More detailed analyses are needed to draw definite conclusions.

\section{5 $\mathrm{O}_{3}$-induced signalling in trees}

$\mathrm{O}_{3}$-signalling events are very quickly initiated during $\mathrm{O}_{3}$ exposure, leading to plant survival or acclimation. Acclimation first implies $\mathrm{O}_{3}$ perception and concomitant signalling cascades, ultimately succeeding in re-programming tree metabolism (Fig. 3). In order to elicit and decipher signalling processes, trees were exposed to acute $\mathrm{O}_{3}$ dose (>150-200 ppb) for few hours. In these conditions, some signalling actors, as calcium or protein kinases, were well characterized in herbaceous plants (Baier et al. 2005; Vainonen and Kangasjarvi 2014; Vaultier and Jolivet 2015). However, $\mathrm{O}_{3}$-induced signalling is by far less documented in trees. Direct extrapolation from model herbaceous plants to trees is not always possible, as woody plants may possess their own defence signalling systems (Dizengremel 2001; Koch et al. 2000). In beech (5560 years old) exposed to an experimental enhanced free-air $\mathrm{O}_{3}$ setting (up to $150 \mathrm{ppb}$ ), the expression level of genes connected with signalling, i.e. ethylene (ET) biosynthesis-related genes ACC (1-aminocyclopropane-1-carboxylic acid) synthase or oxidase, was increased (Jehnes et al. 2007; Olbrich et al. 2010a). Besides, an environmental genomic study performed on 5-year-old trembling aspen exposed to 1.5 times ambient $\mathrm{O}_{3}$ showed that many genes involved in signal transduction were upregulated, e.g. ET biosynthesisrelated genes such as ACC oxidase or a gene coding for a mitogen-activated protein kinase (MAPK) (Gupta et al. 2005). MAPK cascades are well-known components of stress-induced signalling pathways, and several studies revealed their activation in response to $\mathrm{O}_{3}$ exposure in herbaceous plants (Ahlfors et al. 2004; Samuel et al. 2000). In trees, Hamel et al. (2005) showed in hybrid poplar cell suspensions and leaf tissue that $\mathrm{O}_{3}(500 \mathrm{ppb})$ induced a rapid and transient activation of at least two MAPKs, independently or upstream of both salicylic acid (SA) and jasmonic acid (JA) signalling. However, to date, involvement of the $\mathrm{O}_{3}$-activated MAPKs in regulating $\mathrm{O}_{3}$ sensitivity in poplar is still to be investigated.

Trees respond to $\mathrm{O}_{3}$ exposure by producing other signalling molecules as ROS (Diara et al. 2005; Moura et al. 2014; Pellinen et al. 1999). The $\mathrm{O}_{3}$-induced ROS production and subsequently the formation of necrosis are part of the 
Fig. 3 Schematic representation of interactions between signalling and detoxification processes in the cell of plants exposed to ozone. The acclimation of the plants to this pollutant is upon a tight control of these two processes. ET ethylene; $J A$ jasmonic acid; $M A P K$ mitogenactivated protein kinase; $S A$ salicylic acid

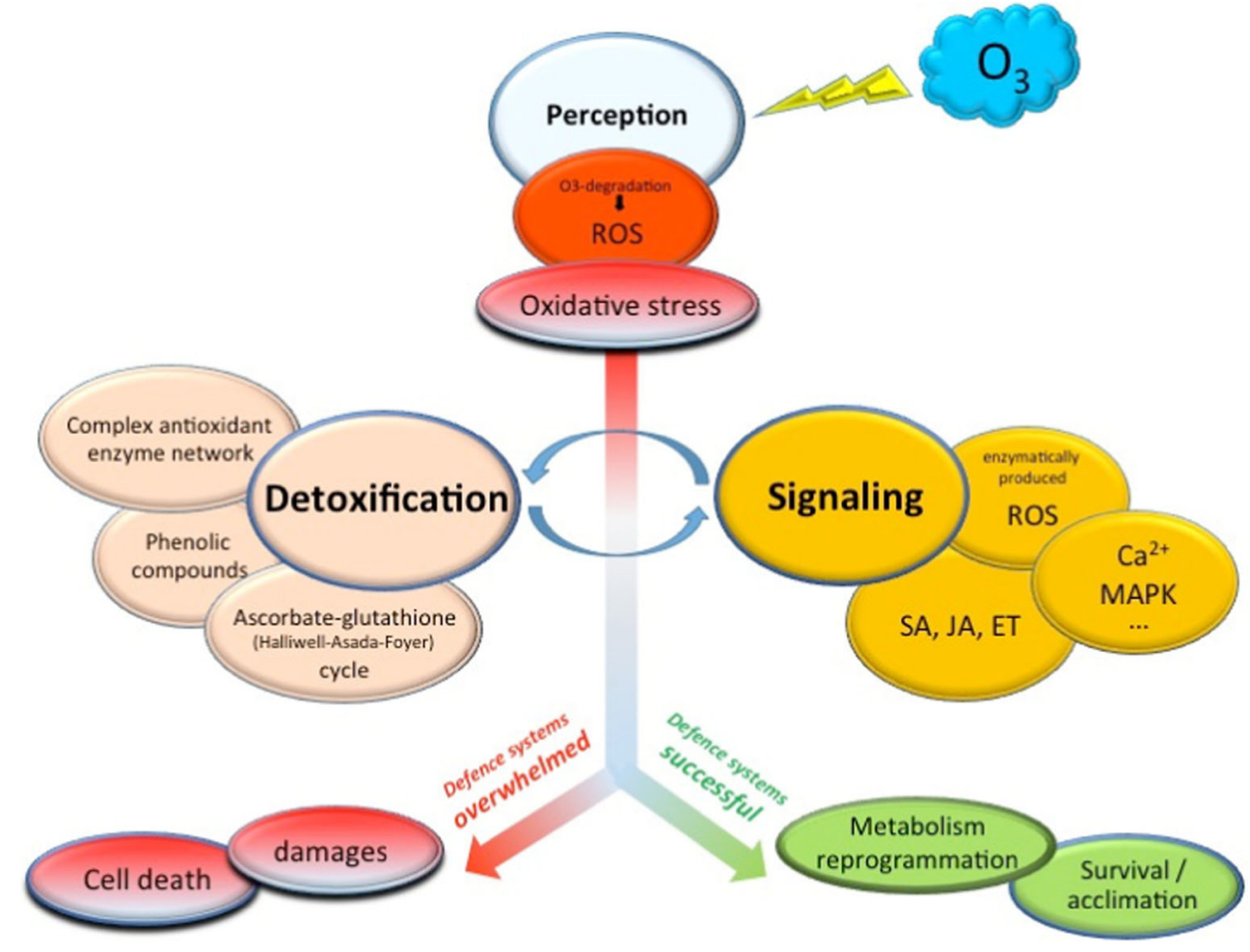

similarities shared with early senescence and hypersensitive response elicited by the incompatible plant-pathogen interaction (Moura et al. 2014; Pellinen et al. 1999; Tuomainen et al. 1996). ROS generated either (i) directly from $\mathrm{O}_{3}$ degradation or (ii) actively enzymatically produced could be crucial components of $\mathrm{O}_{3}$-induced signalling (Vainonen and Kangasjarvi 2014).

Concerning hormones, Koch et al. (1998) suggested the role of SA in mediating some $\mathrm{O}_{3}$-induced responses in trees. $\mathrm{O}_{3}$ can induce lesion formation via the activation of programmed cell death, and SA perception is required for the activation of a hypersensitive cell death pathway (Koch et al. 2000). Poplar has higher constitutive levels of free SA compared with herbaceous plant species such as tobacco and Arabidopsis (Diara et al. 2005; Koch et al. 2000). In birch and in hybrid aspen, free SA accumulated in response to acute $\mathrm{O}_{3}$ conditions (Vahala et al. 2003a; Vahala et al. 2003b). Similarly, a significant increase in the conjugated pool of SA was observed in poplar during acute $\mathrm{O}_{3}$ fumigation (150 ppb for $5 \mathrm{~h}$ ) (Diara et al. 2005). Optimal SA concentration is required to fine-tune the plant response in order to achieve the maximum stimulation of defence responses with minimal induction of cell death (Diara et al. 2005). JA was also evidenced as an important $\mathrm{O}_{3}$-induced signal molecule in trees as acute $\mathrm{O}_{3}$ exposure increases endogenous JA levels in poplar or in birch (Koch et al. 2000; Koch et al. 1998; Vahala et al. 2003b). JA has at least two different roles in $\mathrm{O}_{3}$ responses: one in lesion formation and the other in lesion containment (Kangasjarvi et al. 2005). Activation of SA- and JA- mediated signalling pathways, which may be important in triggering defence responses against oxidative stress, leads to $\mathrm{O}_{3}$ tolerance (Koch et al. 1998). Lesion propagation and containment in $\mathrm{O}_{3}$ damage are under the control of ET (Kangasjarvi et al. 2005). $\mathrm{O}_{3}$ exposure leads to ET release from leaves, in poplar clones (Diara et al. 2005; Kargiolaki et al. 1991), in birch (Vahala et al. 2003b) and in pine needles (Telewski 1992). In aspen, $\mathrm{O}_{3}$ caused a clear concentrationdependent response in ET evolution (Vahala et al. 2003a). Marked increases in the pool of free ACC, precursor of ET, and in ACC synthase transcripts were also detected in poplar (Diara et al. 2005). The role of ET under chronic (75 ppb) and acute $\mathrm{O}_{3}$ (up to $200 \mathrm{ppb}$ ) was investigated in aspen and silver birch by Vahala et al. (2003a; 2003b). Comparing results obtained on different species, herbaceous or not, Diara et al. (2005) hypothesized a "pro-survival" role for ET and the existence of a threshold below which ET would not trigger lesion development. ET can serve as a mediator of either survival or cell death, depending on the magnitude of synthesis and its temporal pattern (Vahala et al. 2003b). In hybrid aspen, ET accelerated leaf senescence under low $\mathrm{O}_{3}$, but under acute $\mathrm{O}_{3}$ elevation, ET signalling seemed to be required for protection from necrotic cell death (Vahala et al. 2003a).

Of course, complex interactions between hormones are involved in tree response to $\mathrm{O}_{3}$ exposure. All the three hormonal signalling pathways: SA, JA and ET, were involved in cell death induced by a short exposure to high $\mathrm{O}_{3}$ concentration (200 ppb for 8 h) in birch (Vahala et al. 2003b). Early high ET production may antagonize the late SA accumulation, and 
conversely, increased SA production may downregulate ET accumulation and thus prevent the ET-dependent cell death (Vahala et al. 2003b). In poplar, difference in $\mathrm{O}_{3}$ sensitivity would depend on differences in the modulation of signal transduction pathways, i.e. the timing and magnitude of SA and ET production, as well as on cross-talking with other signalling molecules (Diara et al. 2005). Further investigations are really needed in trees to unravel this puzzling network triggered by $\mathrm{O}_{3}$, particularly under realistic chronic $\mathrm{O}_{3}$ doses. In these conditions, not only the signalling pathways at the onset of an $\mathrm{O}_{3}$ episode in natural conditions must be considered but also the impacts, some days or weeks later, when the cellular defence mechanisms are overwhelmed, followed with the beginning of cell death and the occurrence of necrosis (Fig. 3). Finally, it is still necessary to decipher the steps by which defence reactions like the ascorbate-glutathione cycle are under the control of signalling (Fig. 3).

\section{Impact of $\mathrm{O}_{3}$ on tree growth, forest productivity and carbon sequestration}

\subsection{Carbon allocation and tree growth}

A meta-analysis by Wittig et al. (2007) concluded that significant decreases in both photosynthesis and stomatal conductance of trees under $\mathrm{O}_{3}$ may negatively affect both carbon sequestration and transpiration. A limitation of extrapolating these data to mature forests is that the estimates are largely based on individual juvenile trees growing in a noncompetitive environment, and extrapolation of results from seedlings may not be appropriate for predicting the response of mature trees and forests to $\mathrm{O}_{3}$ (Chappelka and Samuelson 1998; Ollinger et al. 1997). But recently, Matyssek et al. (2010a) concluded that adult and juvenile trees of pioneer and climax tree species show similar growth sensitivity to chronic $\mathrm{O}_{3}$ stress, although the underlying response mechanisms may differ. Tree growth and productivity are expected to decrease under $\mathrm{O}_{3}$ considering aforementioned effects of this pollutant (Fig. 2). Indeed, lower growth and diameter have been observed in a wide range of tree species after long-term exposure to $\mathrm{O}_{3}$ (Booker et al. 2009; Karnosky et al. 2005; King et al. 2005; McLaughlin et al. 2007; Pretzsch et al. 2010; Tjoelker et al. 1994). Summarizing hundreds of studies, Wittig et al. (2009) reported a decrease in total biomass, leaf area, root to shoot ratio, height and diameter in trees exposed to chronic $\mathrm{O}_{3}$ concentration (in the range $40-100 \mathrm{ppb}$ ) relative to charcoal-filtered atmosphere. However, the intensity of $\mathrm{O}_{3}$ effects on tree carbon uptake and growth differs depending on tree age, the loss in biomass production following $\mathrm{O}_{3}$ exposure being greater in young compared to older trees (Herbinger et al. 2005). Since $\mathrm{O}_{3}$ reduces carbon gain by limiting stomatal diffusion, lowering Rubisco activity, inducing early senescence and increasing carbon cost for tissue repair and antioxidant synthesis, it drastically decreases source strength and carbon availability for export to sink tissues. Additionally, increased soluble sugar content and carbohydrate retention have been observed in source tissue exposed to chronic $\mathrm{O}_{3}$ concentration (from 0 to $110 \mathrm{ppb}$ ) (Friend and Tomlinson 1992; Grantz and Farrar 1999; Grantz and Yang 2000), suggesting a decrease in carbon export under $\mathrm{O}_{3}$. A lower leaf sucrose export and higher carbohydrate level would lead to feedback regulation of photosynthesis and therefore partly explain the reduction in carbon assimilation. Several works have shown a decrease in allocation to roots and root to shoot biomass ratio in response to $\mathrm{O}_{3}$ (Gorissen et al. 1994; Grantz and Farrar 2000; Grantz and Yang 2000; Rennenberg et al. 1996; Spence et al. 1990). Given that mature leaves preferentially allocate carbon resources to stems and roots (Gordon and Larson 1970; Matyssek et al. 2010b; Rangnekar and Forward 1969), it appears logical that the $\mathrm{O}_{3}$-induced early senescence would primarily affect root growth. Such modification may therefore have drastic impacts on tree surrounding rhizosphere and tree survival to environmental constraints such as drought (Agathokleous et al. 2016).

\subsection{Ozone impact on forest productivity and carbon sequestration: results from free-air fumigation experiments and modelling studies}

Fowler et al. (1999) used the 3-D chemistry-transport model STOCHEM (Collins et al. 1997) to simulate the global distribution of tropospheric $\mathrm{O}_{3}$ from 1860 to 2100. The results indicate that the area covered by forests exposed to $>60 \mathrm{ppb}$ increased from 0 in 1860 to 8.3 million $\mathrm{km}^{2}$ in 1990 , i.e. $24 \%$ of global forest area. According to this study, this area could reach 17 million $\mathrm{km}^{2}$ in 2100 , that is half of the projected global forest area, if precursor emission rates remain constant (Fowler et al. 1999). In order to advance from exposure assessment to impact prediction, subsequent modelling studies implemented the linear empirical model of $\mathrm{O}_{3}$ impact on tree biomass production developed from experimental data in the pioneer work of Reich (1987). The results indicated that biomass production of forest ecosystems would be reduced by $3-22 \%$ in the northeastern USA as an effect of tropospheric $\mathrm{O}_{3}$ concentrations recorded during the period 1987-1992 (Ollinger et al. 1997). With a similar approach, Subramanian et al. (2015) found that biomass growth of forest trees in Sweden could be reduced annually by $4.3-15.5 \%$ for conifers and $1.4-4.3 \%$ for birch by current $\mathrm{O}_{3}$ when compared to prehistoric $\mathrm{O}_{3}$. Proietti et al. (2016), by combining satellite productivity estimates, $\mathrm{O}_{3}$ measurement data and impact functions, found that current $\mathrm{O}_{3}$ concentrations could reduce gross primary productivity of European forests by $0.4-30 \%$ 
along a North-West-South-East transect. An alternative, flux-based methodology emerged from the International Cooperative Programme on the effects of air pollution on vegetation (Mills et al. 2013) under the UNECE Convention on Long-Range Transboundary Air Pollution (LRTAP). In this approach, the European Monitoring and Evaluation Program (EMEP) and Rossby Centre Regional Climate (RCA3) models provided $\mathrm{O}_{3}$ and meteorological input data that fed the Deposition of Ozone for Stomatal Exchange $\left(\mathrm{DO}_{3} \mathrm{SE}\right)$ model, which simulates $\mathrm{O}_{3}$ dry deposition (Büker et al. 2012) and subsequently $\mathrm{O}_{3}$ stomatal fluxes and phytotoxic $\mathrm{O}_{3}$ doses $\left(\mathrm{POD}_{\mathrm{Y}}\right)$ as described in the LRTAP convention manual (2010). $\mathrm{O}_{3}$ flux-response relationships were applied to calculate biomass and carbon losses for tree species groups and representative species. The data were combined to land cover data and overlain to EMEP and RCA3 resolved grids. Finally, European forest inventory and carbon sequestration datasets were used to calculate absolute carbon losses due to $\mathrm{O}_{3}$ in Europe. Applying a generic parameterization for deciduous and conifer trees, the authors estimated a reduction of carbon sequestration in the living biomass of trees by $12 \%$ (EMEP input data) to $16 \%$ (RCA3 input data) for the year 2000 as compared to pre-industrial $\mathrm{O}_{3}$ levels (Mills et al. 2013).

Either exposure- or flux-based modelling studies provide congruent estimates of forest biomass production reduction as an effect of current $\mathrm{O}_{3}$. However, the impact functions used rely on $\mathrm{O}_{3}$ exposure- or flux-response relationships that were derived for relatively young trees $(<10$ years of age) exposed to $\mathrm{O}_{3}$ under semi-natural, non-competitive conditions (Karlsson et al. 2007; Reich 1987). Although epidemiological studies suggest that such functions are applicable to mature trees within forest stands (Braun et al. 2010), whether conclusions on the effects of $\mathrm{O}_{3}$ on forests can be drawn from the extrapolation of results obtained on seedlings remains a matter of debate (Samuelson and Kelly 2001). In this respect, the free-air concentration enrichment experiment Aspen FACE led in Rhinelander (WI, USA) provided concordant results. In this study, young forest stands were subjected to an $\mathrm{O}_{3}$ enriched atmosphere $(1.5 \times$ ambient $)$ during 11 years from seedling establishment to maturity (Karnosky et al. 2003). The results showed significant reductions in the total biomass of young stands of trembling aspen $(-23 \%)$, aspen-sugar maple $(-14 \%)$ and aspen-paper birch $(-13 \%)$ (King et al. 2005), but these results reflect in main part the impact of $\mathrm{O}_{3}$ on young trees during their initial, rapid growth stage. Because it was conducted on a mature forest stand composed of 60-yearold trees in a 30-m closed canopy, the free-air $\mathrm{O}_{3}$ fumigation experiment led in the Kranzberg forest in Germany represents a valuable alternative to FACE systems (Matyssek et al. 2010b). This study showed that stem biomass production of beech trees exposed to elevated $\mathrm{O}_{3}(2 \times$ ambient, $<150 \mathrm{ppb})$ during 8 years was reduced by more than $40 \%$, but also highlighted the strong influence of environmental factors such as drought on tree responses to $\mathrm{O}_{3}$. The combination of stem growth, sap flow velocity and $\mathrm{O}_{3}$ measurements has been used to investigate the effect of $\mathrm{O}_{3}$ on mature trees in a mixed deciduous forest in eastern Tennessee (USA) (McLaughlin et al. 2007). This study revealed that daily events of high $\mathrm{O}_{3}$ exposure (daily maximum hour $\geq 100 \mathrm{ppb}$ for 1 day or $\geq 85 \mathrm{ppb}$ for two consecutive days) could decrease stem growth by up to 30 to $50 \%$ over a season, which suggests that episodes of acute exposure might have consequences on tree biomass production that modelling approaches cannot predict. Combined with climate-controlled branch cuvettes, sap flow measurements could represent a valuable alternative to heavy and expensive free-air fumigation experiments for studying the impact of $\mathrm{O}_{3}$ on adult forest trees (Wieser et al. 2012).

Meta-analyses (Wittig et al. 2009) as well as modelling studies based on response functions estimate that $\mathrm{O}_{3}$ has a significant impact ( -5 to $-30 \%)$ on the net primary productivity of forest ecosystems, which might impair their capacity for carbon sequestration (Ainsworth et al. 2012). However, field experiments on mature forest stands have shown that many factors can modulate tree responses to the pollutant (e.g. environmental conditions, stand dynamics and competition) and remain to be considered in modelling approaches. The main challenge of stomatal deposition models is to accurately predict stomatal conductance in response to environmental drivers (Emberson et al. 2000). Recently, Fares et al. (2013a), Hoshika et al. (2011) and Nunn et al. (2010) applied Jarvis's model parameterized with environmental observations with field data, and they were able to predict well stomatal conductance. The recent study of Wang et al. (2016), which simulated the $\mathrm{O}_{3}$ impact on forest composition and ecosystem dynamics over 500 years, indicated that elevated $\mathrm{O}_{3}$ could even lead to an increase in forest productivity due to diversity change and compensatory processes at the community scale.

\section{Combination of $\mathrm{O}_{3}$ and other environmental factors}

The interaction of $\mathrm{O}_{3}$ with other abiotic or biotic factors can first be considered through its combination with other pollutants, which can occur simultaneously or sequentially. A review on tree exposure to pollutant mixtures showed that the observed responses were highly variable according to tree species, age, genotype, composition of rain solution and soil type (Chappelka and Chevone 1992). In a context of global change, a range of constraints, including high $\mathrm{CO}_{2}$, increased temperature, altered precipitation and drought episodes, will also affect trees exposed to $\mathrm{O}_{3}$ pollution episodes. A first interaction has been investigated in a context of rising atmospheric $\mathrm{CO}_{2}$ concentrations, which 
generally results in a reduction of stomatal conductance (Ainsworth et al. 2012). Thus, based on simulated stomatal $\mathrm{O}_{3}$ uptake, the flux of $\mathrm{O}_{3}$ entering the leaves would be decreased (Klingberg et al. 2011; Sitch et al. 2007). However, the reduced stomatal conductance on a longterm exposure under high $\mathrm{CO}_{2}$ seems uncertain considering contrasting results from FACE experiments (Uddling et al. 2010). The stage of plant and stand development, as well as the consideration of overstorey/understorey species, would influence the stomatal response. Drought also reduces stomatal conductance, with a potential subsequent restriction of $\mathrm{O}_{3}$ effects. In fact, the protective effect of drought would only occur in severe drought conditions while under low water restriction the damage caused by $\mathrm{O}_{3}$ appeared additive (Matyssek et al. 2006; Pääkkönen et al. 1998b). However, there are clear inter- and intraspecific differences in response to the combination of drought and $\mathrm{O}_{3}$ (Dixon et al. 1998). The protective effect of drought may be the result of stomatal exclusion of $\mathrm{O}_{3}$ but also the induction of defence reactions (Matyssek et al. 2006). Other works underlined that the combined effects of drought and $\mathrm{O}_{3}$ could also decrease the antioxidant capacity of leaf cells in a higher extent than with the constraint alone, leading to a higher susceptibility to oxidative stress (Wellburn et al. 1996). Thus, in these conditions of combined stresses, the fine-tuning between $\mathrm{O}_{3}$ uptake and defence capacity appears crucial (Matyssek et al. 2006). Because of changes in plant metabolism, carbon assimilation and allocation and chemical leaf defences, $\mathrm{O}_{3}$ may also modify plant responses to biotic factors as insect or plant pathogens. Trees can be weakened by $\mathrm{O}_{3}$, promoting biotic attack (Chappelka and Chevone 1992; Dowding 1988). However, these studies also underlined that a great number of factors linked to the environment, the host plant or the pathogen may modulate the $\mathrm{O}_{3}$-host-pathogen interactions and their consequences. Some works attempted to better understand these interactions and identify underlying biochemical and physiological mechanisms. Using Aspen FACE, investigations were carried out on the impact of both increased $\mathrm{CO}_{2}$ and $\mathrm{O}_{3}$ concentrations on forest insects in a poplar canopy (Percy et al. 2002). In response to $\mathrm{O}_{3}$, the production and chemical composition of leaf cuticular waxes and the concentrations of protective compounds in the leaf were modified. These modifications may explain an increase in rust infection under $\mathrm{O}_{3}$ while a higher abundance of leaf-chewing insects as well as aphids have been observed, an effect alleviated by the combination of $\mathrm{CO}_{2}$ and $\mathrm{O}_{3}$. Changes in leaf morphology and composition, including phenolic content, induced by $\mathrm{O}_{3}$ appeared to be determinant in explaining the larger deleterious effect of an herbivorous insect on $\mathrm{O}_{3}$-treated aspen trees (Freiwald et al. 2008). Finally, the $\mathrm{O}_{3}$ impact on carbon allocation must be also considered as a factor that modulates the beneficial interaction of fungi and plants via mycorrhization (Nikolova et al. 2010; Pritsch et al. 2009), an aspect that needs to be clarified.

\section{Concluding remarks}

It is now widely accepted that $\mathrm{O}_{3}$ is able to reduce the growth of forest trees. Even though the results could differ in intensity between experiments conducted in phytotrons or in FACE systems, between young and mature trees, the major impact is a decreased carbon assimilation resulting in a reduced carbon sequestration. The precise mechanisms leading to this loss of available carbon are still to be totally deciphered, notably the respective roles of stomatal resistance and detoxification processes, which determine the tree sensitivity. In addition, the mechanisms underlying the $\mathrm{O}_{3}$ transduction signal begin to be clarified in acute conditions while it remains fragmented in chronic $\mathrm{O}_{3}$ exposure, particularly for trees. Another consequence of the $\mathrm{O}_{3}$ effect is the modification of carbon allocation to the different organs of the tree, which can lead to changes in wood quality and quantity. In this context, alterations of the functioning of forest ecosystems need also to be better investigated by taking into account the interactions between $\mathrm{O}_{3}$ and other abiotic $\left(\mathrm{CO}_{2}\right.$, water, temperature, etc. $)$ and biotic stresses. Emphasis should be put on water availability, a factor already mentioned as determinant to scale $\mathrm{O}_{3}$ effects from seedlings to forest trees (Samuelson and Kelly 2001). Contradictory reports of antagonistic or synergetic effects of $\mathrm{O}_{3}$ and $\mathrm{CO}_{2}$ or drought clearly show that additional research effort is needed. The advancement of an integrative knowledge of $\mathrm{O}_{3}$ impact from the leaf cell to the tree level will allow a significant improvement of the existing models of $\mathrm{O}_{3}$ risk assessment on ecosystems.

Acknowledgments The UMR 1137 EEF is supported by the French National Research Agency through the Laboratory of Excellence ARBRE (ANR-12- LABXARBRE-01).

\section{References}

Agathokleous E, Saitanis CJ, Wang XN, Watanabe M, Koike T (2016) A review study on past 40 years of research on effects of tropospheric $\mathrm{O}_{3}$ on belowground structure, functioning, and processes of trees: a linkage with potential ecological implications. Water Air Soil Pollut 227. doi:10.1007/s11270-015-2715-9

Ahlfors R, Macioszek V, Rudd J, Brosche M, Schlichting R, Scheel D, Kangasjarvi J (2004) Stress hormone-independent activation and nuclear translocation of mitogen-activated protein kinases in Arabidopsis thaliana during ozone exposure. Plant J 40:512-522. doi:10.1111/j.1365-313X.2004.02229.x

Ainsworth EA, Yendrek CR, Sitch S, Collins WJ, Emberson LD (2012) The effects of tropospheric ozone on net primary productivity and implications for climate change. Annu Rev Plant Biol 63:637-661. doi:10.1146/annurev-arplant-042110-103829 
Andreae MO, Artaxo P, Brandao C, Carswell FE, Ciccioli P, da Costa AL, Culf AD, Esteves JL, Gash JHC, Grace J, Kabat P, Lelieveld J, Malhi Y, Manzi AO, Meixner FX, Nobre AD, Nobre C, Ruivo M, Silva-Dias MA, Stefani P, Valentini R, von Jouanne J, Waterloo MJ (2002) Biogeochemical cycling of carbon, water, energy, trace gases, and aerosols in Amazonia: the LBA-EUSTACH experiments. J Geophys Res-Atmos 107. doi:10.1029/2001jd000524

Ashmore MR, Büker P, Emberson LD, Terry AC, Toet S (2007) Modelling stomatal ozone flux and deposition to grassland communities across Europe. Environ Pollut 146:659-670. doi:10.1016/j.envpol.2006.06.021

Bagard M, Le Thiec D, Delacote E, Hasenfratz-Sauder MP, Banvoy J, Gerard J, Dizengremel P, Jolivet Y (2008) Ozone-induced changes in photosynthesis and photorespiration of hybrid poplar in relation to the developmental stage of the leaves. Physiol Plant 134:559-574. doi:10.1111/j.1399-3054.2008.01160.x

Baier M, Kandlbinder A, Golldack D, Dietz KJ (2005) Oxidative stress and ozone: perception, signalling and response. Plant Cell Environ 28:1012-1020. doi:10.1111/J.1365-3040.2005.01326.X

Baldantoni D, Fagnano M, Alfani A (2011) Tropospheric ozone effects on chemical composition and decomposition rate of Quercus ilex L. leaves. Sci Total Environ 409:979-984. doi:10.1016/j.scitotenv.2010.11.022

Barnosky AD, Hadly EA, Bascompte J, Berlow EL, Brown JH, Fortelius M, Getz WM, Harte J, Hastings A, Marquet PA, Martinez ND, Mooers A, Roopnarine P, Vermeij G, Williams JW, Gillespie R, Kitzes J, Marshall C, Matzke N, Mindell DP, Revilla E, Smith AB (2012) Approaching a state shift in Earth's biosphere. Nature 486: 52-58. doi:10.1038/nature11018

Becker KH, Fricke W, Lobel J, Schurath U (1985) Formation, transport, and control of photochemical oxidants. In: Guderian R (ed) Air pollution by photochemical oxidants, vol 52. Ecological studies. Springer-Verlag, Berlin Heidelberg, pp. 3-125. doi:10.1007/978-3-642-70118-4

Behnke K, Kleist E, Uerlings R, Wildt J, Rennenberg H, Schnitzler JP (2009) RNAi-mediated suppression of isoprene biosynthesis in hybrid poplar impacts ozone tolerance. Tree Physiol 29:725-736. doi:10.1093/treephys/tpp009

Bernardi R, Nali C, Ginestri P, Pugliesi C, Lorenzini G, Durante M (2004) Antioxidant enzyme isoforms on gels in two poplar clones differing in sensitivity after exposure to ozone. Biol Plant 48:41-48. doi:10.1023/B:Biop.0000024273.35976.Cb

Betz GA, Knappe C, Lapierre C, Olbrich M, Welzl G, Langebartels C, Heller W, Sandermann H, Ernst D (2009) Ozone affects shikimate pathway transcripts and monomeric lignin composition in European beech (Fagus sylvatica L. Eur J For Res 128:109116. doi:10.1007/S10342-008-0216-8

Blokhina O, Virolainen E, Fagerstedt KV (2003) Antioxidants, oxidative damage and oxygen deprivation stress: a review. Ann Bot 91:179194. doi:10.1093/aob/mcf118

Boerner REJ, Rebbeck J (1995) Decomposition and nitrogen release from leaves of three Harwood species grown under elevated $\mathrm{O}_{3}$ and/or $\mathrm{CO}_{2}$. Plant Soil 170:149-157

Bohler S, Bagard M, Oufir M, Planchon S, Hoffmann L, Jolivet Y, Hausman JF, Dizengremel P, Renaut J (2007) A DIGE analysis of developing poplar leaves subjected to ozone reveals major changes in carbon metabolism. Proteomics 7:1584-1599. doi:10.1002/pmic.200600822

Booker FL, Anttonen S, Heagle AS (1996) Catechin, proanthocyanidin and lignin contents of loblolly pine (Pinus taeda) needles after chronic exposure to ozone. New Phytol 132:483-492. doi:10.1111/J.1469-8137.1996.Tb01868.X

Booker F, Muntifering R, Mcgrath M, Burkey K, Decoteau D, Fiscus E, Manning W, Krupa S, Chappelka A, Grantz D (2009) The ozone component of global change: potential effects on agricultural and horticultural plant yield, product quality and interactions with invasive species. J Integr Plant Biol 51:337-351. doi:10.1111/j.1744-7909.2008.00805.x

Braun S, Schindler C, Leuzinger S (2010) Use of sap flow measurements to validate stomatal functions for mature beech (Fagus sylvatica) in view of ozone uptake calculations. Environ Pollut 158:2954-2963. doi:10.1016/J.Envpol.2010.05.028

Brendley BW, Pell EJ (1998) Ozone-induced changes in biosynthesis of Rubisco and associated compensation to stress in foliage of hybrid poplar. Tree Physiol 18:81-90. doi:10.1093/treephys/18.2.81

Büker P, Morrissey T, Briolat A, Falk R, Simpson D, Tuovinen JP, Alonso R, Barth S, Baumgarten M, Grulke N, Karlsson PE, King J, Lagergren F, Matyssek R, Nunn A, Ogaya R, Peñuelas J, Rhea L, Schaub M, Uddling J, Werner W, Emberson LD (2012) DO3SE modelling of soil moisture to determine ozone flux to forest trees. Atmos Chem Phys 12:5537-5562. doi:10.5194/acp-12-5537-2012

Büker P, Feng Z, Uddling J, Briolat A, Alonso R, Braun S, Elvira S, Gerosa G, Karlsson PE, Le Thiec D, Marzuoli R, Mills G, Oksanen E, Wieser G, Wilkinson M, Emberson LD (2015) New flux based dose-response relationships for ozone for European forest tree species. Environ Pollut 206 4:163-174.doi:10.1016/j. envpol.2015.06.033

Bussotti F, Ferretti M (2009) Visible injury, crown condition, and growth responses of selected Italian forests in relation to ozone exposure. Environ Pollut 157:1427-1437. doi:10.1016/j.envpol.2008.09.034

Cabané M, Afif D, Hawkins S (2012) Lignins and abiotic stresses. Adv Bot Res 61:219-262. doi:10.1016/B978-0-12-416023-1.00007-0

Cabané M, Pireaux JC, Leger E, Weber E, Dizengremel P, Pollet B, Lapierre C (2004) Condensed lignins are synthesized in poplar leaves exposed to ozone. Plant Physiol 134:586-594. doi:10.1104/pp.103.031765

Calfapietra C, Mugnozza GS, Karnosky DF, Loreto F, Sharkey TD (2008) Isoprene emission rates under elevated $\mathrm{CO}_{2}$ and $\mathrm{O}_{3}$ in two field-grown aspen clones differing in their sensitivity to $\mathrm{O}_{3}$. New Phytol 179:55-61. doi:10.1111/j.1469-8137.2008.02493.x

Cape JN, Hamilton R, Heal MR (2009) Reactive uptake of ozone at simulated leaf surfaces: implications for 'non-stomatal' ozone flux. Atmos Environ 43:1116-1123. doi:10.1016/j.atmosenv.2008.11.007

Castagna A, Ranieri A (2009) Detoxification and repair process of ozone injury: from $\mathrm{O}_{3}$ uptake to gene expression adjustment. Environ Pollut 157:1461-1469. doi:10.1016/j.envpol.2008.09.029

Chappelka AH, Chevone BI (1992) Tree responses to ozone. In: Lefohn AS (ed) Surface level ozone exposures and their effects on vegetation. Lewis, Chelsea, pp 271-324

Chappelka AH, Samuelson LJ (1998) Ambient ozone effects on forest trees of the eastern United States: a review. New Phytol 139:91-108. doi:10.1046/j.1469-8137.1998.00166.x

Cieslik S (2009) Ozone fluxes over various plant ecosystems in Italy: a review. Environ Pollut 157:1487-1496. doi:10.1016/j.envpol.2008.09.050

Collins WJ, Stevenson DS, Johnson CE, Derwent RG (1997) Tropospheric ozone in a global-scale three-dimensional Lagrangian model and its response to $\mathrm{NO}_{\mathrm{x}}$ emission controls. J Atmos Chem 26:223-274. doi:10.1023/A:1005836531979

Conklin PL, Barth C (2004) Ascorbic acid, a familiar small molecule intertwined in the response of plants to ozone, pathogens, and the onset of senescence. Plant Cell Environ 27:959-970. doi:10.1111/ J.1365-3040.2004.01203.X

Dalstein L, Torti X, Le Thiec D, Dizengremel P (2002) Physiological study of declining Pinus cembra (L.) trees in southern France. Trees 16:299-305. doi:10.1007/s00468-001-0160-4

Danielsson H, Karlsson GP, Karlsson PE, Pleijel H (2003) Ozone uptake modelling and flux-response relationships - an assessment of ozone-induced yield loss in spring wheat. Atmos Environ 37:475485. doi:10.1016/s1352-2310(02)00924-x 
de Temmerman L, Vandermeiren K, D'Haese D, Bortier K, Asard H, Ceulemans R (2002) Ozone effects on trees, where uptake and detoxification meet. Dendrobiology 47:9-19

de Vries W, Dobbertin MH, Solberg S, van Dobben HF, Schaub M (2014) Impacts of acid deposition, ozone exposure and weather conditions on forest ecosystems in Europe: an overview. Plant Soil 380:1-45. doi:10.1007/s11104-014-2056-2

Dence C (1992) The determination of lignin. In: Lin S, Dence C (eds) Methods in lignin chemistry. Springer-Verlag, Berlin, Germany, pp. 33-62

Dentener F, Stevenson D, Cofala J, Mechler R, Amann M, Bergamaschi P, Raes F, Derwent R (2005) The impact of air pollutant and methane emission controls on tropospheric ozone and radiative forcing: CTM calculations for the period 1990-2030. Atmos Chem Phys 5:17311755. doi:10.5194/acp-5-1731-2005

Dghim AA, Dumont J, Hasenfratz-Sauder MP, Dizengremel P, Le Thiec D, Jolivet Y (2013a) Capacity for NADPH regeneration in the leaves of two poplar genotypes differing in ozone sensitivity. Physiol Plant 148:36-50. doi:10.1111/j.1399-3054.2012.01686.x

Dghim AA, Mhamdi A, Vaultier MN, Hasenfratz-Sauder MP, Le Thiec D, Dizengremel P, Noctor G, Jolivet Y (2013b) Analysis of cytosolic isocitrate dehydrogenase and glutathione reductase 1 in photoperiod-influenced responses to ozone using Arabidopsis knockout mutants. Plant Cell Environ 36:1981-1991. doi:10.1111/Pce.12104

Di Baccio D, Castagna A, Paoletti E, Sebastiani L, Ranier A (2008) Could the differences in $\mathrm{O}_{3}$ sensitivity between two poplar clones be related to a difference in antioxidant defense and secondary metabolic response to $\mathrm{O}_{3}$ influx? Tree Physiol 28:1761-1772. doi:10.1093/treephys/28.12.1761

Diara C, Castagna A, Baldan B, Mensuali-Sodi A, Sahr T, Langebartels C, Sebastiani L, Ranieri A (2005) Differences in the kinetics and scale of signalling molecule production modulate the ozone sensitivity of hybrid poplar clones: the roles of $\mathrm{H}_{2} \mathrm{O}_{2}$, ethylene and salicylic acid. New Phytol 168:351-364. doi:10.1111/j.1469-8137.2005.01514.x

Dixon M, Le Thiec D, Garrec JP (1998) Reactions of Norway spruce and beech trees to 2 years of ozone exposure and episodic drought. Environ Exp Bot 40:77-91. doi:10.1016/s0098-8472(98)00023-9

Dizengremel P (2001) Effects of ozone on the carbon metabolism of forest trees. Plant Physiol Biochem 39:729-742. doi:10.1016/S0981-9428(01)01291-8

Dizengremel P, Jolivet Y, Tuzet A, Ranieri A, Le Thiec D (2013) Integrative leaf-level phytotoxic ozone dose assessment for forest risk modelling. In: Matyssek R, Clarke N, Cudlin P et al. (eds) Developments in environmental science, vol 13. Elsevier, pp 267 288. doi:10.1016/B978-0-08-098349-3.00013-X

Dizengremel P, Le Thiec D, Bagard M, Jolivet Y (2008) Ozone risk assessment for plants: central role of metabolism-dependent changes in reducing power. Environ Pollut 156:11-15. doi:10.1016/j.envpol.2007.12.024

Dizengremel P, Le Thiec D, Hasenfratz-Sauder MP, Vaultier MN, Bagard M, Jolivet Y (2009) Metabolic-dependent changes in plant cell redox power after ozone exposure. Plant Biol 11:35-42

Dizengremel P, Sasek TW, Brown KJ, Richardson CJ (1994) Ozoneinduced changes in primary carbon metabolism enzymes of loblolly pine needles. J Plant Physiol 144:300-306. doi:10.1016/S0176-1617(11)81191-0

Dizengremel P, Vaultier MN, Le Thiec D, Cabané M, Bagard M, Gerant D, Gerard J, Dghim AA, Richet N, Afif D, Pireaux JC, HasenfratzSauder MP, Jolivet Y (2012) Phosphoenolpyruvate is at the crossroads of leaf metabolic responses to ozone stress. New Phytol 195: 512-517. doi:10.1111/j.1469-8137.2012.04211.x

Dizengremel P, Jolivet Y, Tuzet A, Ranieri A, Le Thiec D (2013) Integrative leaf-level phytotoxic ozone dose assessment for forest risk modelling. In: Matyssek R, Clarke N, Cudlin P et al. (eds)
Developments in environmental science, vol 13. Elsevier, pp 267288. doi:10.1016/B978-0-08-098349-3.00013-x

Dizhbite T, Telysheva G, Jurkjane V, Viesturs U (2004) Characterization of the radical scavenging activity of lignins - natural antioxidants. Bioresour Technol 95:309-317. doi:10.1016/j.biortech.2004.02.024

Dowding P (1988) Air pollutant effects on plant pathogens. In: SchulteHostede S, Darrall NM, Blank LW, Wellburn AR (eds) Air pollution and plant metabolism. Elsevier Applied Science, London, pp. 329-380

Dumont J, Keski-Saari S, Keinanen M, Cohen D, Ningre N, KontunenSoppela S, Baldet P, Gibon Y, Dizengremel P, Vaultier M-N, Jolivet Y, Oksanen E, Le Thiec D (2014) Ozone affects ascorbate and glutathione biosynthesis as well as amino acid contents in three Euramerican poplar genotypes. Tree Physiol 34:253-266. doi:10.1093/treephys/tpu004

Dumont J, Spicher F, Montpied P, Dizengremel P, Jolivet Y, Le Thiec D (2013) Effects of ozone on stomatal responses to environmental parameters (blue light, red light, $\mathrm{CO}_{2}$ and vapour pressure deficit) in three Populus deltoides x Populus nigra genotypes. Environ Pollut 173:85-96

Emberson LD, Ashmore MR, Cambridge HM, Simpson D, Tuovinen JP (2000) Modelling stomatal ozone flux across Europe. Environ Pollut 109:403-413. doi:10.1016/S0269-7491(00)00043-9

Ernst D (2013) Integrated studies on abiotic stress defence in trees: the case of ozone. In: Matyssek R, Clarke N, Cudlin P, et al. (eds) Climate change, air pollution and global challenges: understanding and perspectives from forest research, vol 13. Developments in Environmental Science. Elsevier Science Bv, Amsterdam, pp. 289-307. doi:10.1016/b978-0-08-098349-3.00014-1

Fares S, Matteucci G, Mugnozza GS, Morani A, Calfapietra C, Salvatori E, Fusaro L, Manes F, Loreto F (2013a) Testing of models of stomatal ozone fluxes with field measurements in a mixed Mediterranean forest. Atmos Environ 67:242-251. doi:10.1016/j.atmosenv.2012.11.007

Fares S, Oksanen E, Lannenpaa M, Julkunen-Tiitto R, Loreto F (2010) Volatile emissions and phenolic compound concentrations along a vertical profile of Populus nigra leaves exposed to realistic ozone concentrations. Photosynth Res 104:61-74. doi:10.1007/s11120-010-9549-5

Fares S, Vargas R, Detto M, Goldstein AH, Karlik J, Paoletti E, Vitale M (2013b) Tropospheric ozone reduces carbon assimilation in trees: estimates from analysis of continuous flux measurements. Glob Change Biol 19:2427-2443. doi:10.1111/gcb.12222

Feng Z, Sun J, Wan W, Hu E, Calatayud V (2014) Evidence of widespread ozone-induced visible injury on plants in Beijing, China. Environ Pollut 193:296-301. doi:10.1016/j.envpol.2014.06.004

Fontan J, Minga A, Lopez A, Druilhet A (1992) Vertical ozone profiles in a pine forest. Atmos Environ 26:863-869. doi:10.1016/0960-1686(92)90245-g

Fowler D, Cape JN, Coyle M, Flechard C, Kuylenstierna J, Hicks K, Derwent D, Johnson C, Stevenson D (1999) The global exposure of forests to air pollutants. Water Air Soil Pollut 116:5-32. doi:10.1023/A:1005249231882

Fowler D, Pilegaard K, Sutton MA, Ambus P, Raivonen M, Duyzer J, Simpson D, Fagerli H, Fuzzi S, Schjoerring JK, Granier C, Neftel A, Isaksen ISA, Laj P, Maione M, Monks PS, Burkhardt J, Daemmgen U, Neirynck J, Personne E, Wichink-Kruit R, Butterbach-Bahl K, Flechard C, Tuovinen JP, Coyle M, Gerosa G, Loubet B, Altimir N, Gruenhage L, Ammann C, Cieslik S, Paoletti E, Mikkelsen TN, RoPoulsen H, Cellier P, Cape JN, Horvath L, Loreto F, Niinemets U, Palmer PI, Rinne J, Misztal P, Nemitz E, Nilsson D, Pryor S, Gallagher MW, Vesala T, Skiba U, Brueggemann N, ZechmeisterBoltenstern S, Williams J, O'Dowd C, Facchini MC, de Leeuw G, Flossman A, Chaumerliac N, Erisman JW (2009) Atmospheric composition change: ecosystems-atmosphere interactions. Atmos Environ 43:5193-5267. doi:10.1016/J.Atmosenv.2009.07.068 
Foyer CH, Noctor G (2011) Ascorbate and glutathione: the heart of the redox hub. Plant Physiol 155:2-18. doi:10.1104/pp.110.167569

Freiwald V, Haikio E, Julkunen-Tiitto R, Holopainen JK, Oksanen E (2008) Elevated ozone modifies the feeding behaviour of the common leaf weevil on hybrid aspen through shifts in developmental, chemical, and structural properties of leaves. Entomol Exp Appl 128:66-72. doi:10.1111/j.1570-7458.2008.00677.x

Friend AL, Tomlinson PT (1992) Mild ozone exposure alters ${ }^{14} \mathrm{C}$ dynamics in foliage of Pinus taeda L. Tree Physiol 11:215-227. doi:10.1093/treephys/11.3.215

Galliano H, Cabané M, Eckerskorn C, Lottspeich F, Sandermann HJ, Ernst D (1993a) Molecular cloning, sequence analysis and elicitor-/ozone-induced accumulation of cinnamyl alcohol dehydrogenase from Norway spruce (Picea abies L). Plant Mol Biol 23:145156. doi:10.1007/BF00021427

Galliano H, Heller W, Sandermann HJ (1993b) Ozone induction and purification of spruce cinnamyl alcohol dehydrogenase. Phytochemistry 32:557-563. doi:10.1016/S0031-9422(00)95136-7

Gaucher C, Costanzo N, Afif D, Mauffette Y, Chevrier N, Dizengremel P (2003) The impact of elevated ozone and carbon dioxide on young Acer saccharum seedlings. Physiol Plant 117:392-402. doi:10.1034 /j.1399-3054.2003.00046.x

Gerosa G, Marzuoli R, Desotgiu R, Bussotti F, Ballarin-Denti A (2009) Validation of the stomatal flux approach for the assessment of ozone visible injury in young forest trees. Results from the TOP (transboundary ozone pollution) experiment at Curno, Italy. Environ Pollut 157:1497-1505. doi:10.1016/j.envpol.2008.09.042

Gielen B, Low M, Deckmyn G, Metzger U, Franck F, Heerdt C, Matyssek R, Valcke R, Ceulemans R (2007) Chronic ozone exposure affects leaf senescence of adult beech trees: a chlorophyll fluorescence approach. J Exp Bot 58:785-795. doi:10.1093/jxb/erl222

Gordon JC, Larson PR (1970) Redistribution of ${ }^{14} \mathrm{C}$-labeled reserve food in young red pines during shoot elongation. For Sci 16:14-20

Gorissen A, Joosten NN, Smeulders SM, Van Veen JA (1994) Effects of short-term ozone exposure and soil water availability on the carbon economy of juvenile Douglas-fir. Tree Physiol 14:647-657. doi:10.1093/treephys/14.6.647

Grantz DA, Farrar JF (1999) Acute exposure to ozone inhibits rapid carbon translocation from source leaves of Pima cotton. J Exp Bot 50:1253-1262. doi:10.1093/Jexbot/50.336.1253

Grantz DA, Farrar JF (2000) Ozone inhibits phloem loading from a transport pool: compartmental efflux analysis in Pima cotton. Aust J Plant Physiol 27:859-868. doi:10.1071/PP99169

Grantz DA, Yang SD (2000) Ozone impacts on allometry and root hydraulic conductance are not mediated by source limitation nor developmental age. J Exp Bot 51:919-927. doi:10.1093/jexbot/51.346.919

Grünhage L, Krupa SV, Legge AH, Jäger HJ (2004) Ambient flux-based critical values of ozone for protecting vegetation: differing spatial scales and uncertainties in risk assessment. Atmos Environ 38: 2433-2437. doi:10.1016/j.atmosenv.2003.12.039

Gunthardt-Goerg M, McQuattie C, Scheidegger C, Rhiner C, Matyssek R (1997) Ozone-induced cytochemical and ultrastructural changes in leaf mesophyll cell walls. Can J For Res 27:453-463. doi:10.1139/cjfr-27-4-453

Gunthardt-Goerg MS, McQuattie CJ, Maurer S, Frey B (2000) Visible and microscopic injury in leaves of five deciduous tree species related to current critical ozone levels. Environ Pollut 109:489-500. doi:10.1016/S0269-7491(00)00052-X

Gupta P, Duplessis S, White H, Karnosky DF, Martin F, Podila GK (2005) Gene expression patterns of trembling aspen trees following long-term exposure to interacting elevated $\mathrm{CO}_{2}$ and tropospheric $\mathrm{O}_{3}$. New Phytol 167:129-142. doi:10.1111/j.1469-8137.2005.01422.x

Haagen-Smit AJ, Darley EF, Zaitlin M, Hull H, Noble W (1952) Investigation on injury to plants from air pollution in the Los Angeles area. Plant Physiol 27:18-34. doi:10.1104/pp.27.1.18
Haberer K, Herbinger K, Alexou M, Tausz M, Rennenberg H (2007) Antioxidative defence of old growth beech (Fagus sylvatica) under double ambient $\mathrm{O}_{3}$ concentrations in a free-air exposure system. Plant Biol 9:215-226. doi:10.1055/s-2007-964824

Haikio E, Freiwald V, Julkunen-Tiitto R, Beuker E, Holopainen T, Oksanen E (2009) Differences in leaf characteristics between ozone-sensitive and ozone-tolerant hybrid aspen (Populus tremula x Populus tremuloides) clones. Tree Physiol 29:53-66. doi:10.1093/Treephys/Tpn005

Hamel LP, Miles GP, Samuel MA, Ellis BE, Seguin A, Beaudoin N (2005) Activation of stress-responsive mitogen-activated protein kinase pathways in hybrid poplar (Populus trichocarpa x Populus deltoides. Tree Physiol 25:277-288. doi:10.1093/treephys/25.3

Heath RL (2008) Modification of the biochemical pathways of plants induced by ozone: what are the varied routes to change? Environ Pollut 155:453-463

Heath RL, Lefohn AS, Musselman RC (2009) Temporal processes that contribute to non linearity in vegetation responses to ozone exposure and dose. Atmos Environ 43:2919-2928. doi:10.1016/j.atmosenv.2009.03.011

Heath RL, Taylor GEJ (1997) Physiological process and plant responses to ozone exposure. In: Sandermann H, Wellburn AR, Heath RL (eds) Forest decline and ozone. A comparison of controlled chamber and field experiments, vol 127. Ecological studies, analysis and synthesis. Springer, Berlin, pp. 317-368. doi:10.1007/978-3-642-59233-1 10

Heller W, Rosemann D, Osswald WF, Benz B, Schönwitz R, Lohwasser K, Kloos M, Sandermann H Jr (1990) Biochemical responses of Norway spruce (Picea abies (L.) Karst.) towards 14-month exposure to ozone and acid mist: part I-effects on polyphenol and monoterpene metabolism. Environ Pollut 64:353-366. doi:10.1016/0269-7491(90)90057-J

Herbinger K, Then C, Low M, Haberer K, Alexous M, Koch N, Remele K, Heerdt C, Grill D, Rennenberg H, Haberle KH, Matyssek R, Tausz M, Wieser G (2005) Tree age dependence and withincanopy variation of leaf gas exchange and antioxidative defence in Fagus sylvatica under experimental free-air ozone exposure. Environ Pollut 137:476-482. doi:10.1016/j.envpol.2005.01.034

Hoshika Y, Shimizu Y, Omasa K (2011) A comparison between stomatal ozone uptake and AOT40 of deciduous trees in Japan. iForest 4: 128-135. doi:10.3832/ifor0573-004

Hoshika Y, Carriero G, Feng Z, Zhang Y, Paoletti E (2014) Determinants of stomatal sluggishness in ozone exposed deciduous tree species. Sci Total Environ 481:453-458. doi:10.1016/j. scitotenv.2014.02.080

IPCC (2013) Summary for policymakers. In: Stocker TF, Qin D, Plattner G-K, et al. (eds) Climate change 2013: the physical science basis. Contribution of working group I to the fifth assessment report of the Intergovernmental Panel on Climate Change. Cambridge University Press, Cambridge

Jacquot JP, Dietz KJ, Rouhier N, Meux E, Lallement PA, Selles B, Hecker A (2013) Redox regulation in plants: glutathione and "redoxin" related families. In: Jakob U, Reichmann D (eds) Oxidative stress and redox regulation. Springer, Netherlands, pp. 213-231. doi:10.1007/978-94-007-5787-5 8

Jaggi M, Ammann C, Neftel A, Fuhrer J (2006) Environmental control of profiles of ozone concentration in a grassland canopy. Atmos Environ 40:5496-5507. doi:10.1016/j.atmosenv.2006.01.025

Jarvis PG (1976) Interpretation of variations in leaf water potential and stomatal conductance found in canopies in field. Philos Trans R Soc Lond Ser B-Biol Sci 273:593-610. doi:10.1098/rstb.1976.0035

Jehnes S, Betz G, Bahnweg G, Haberer K, Sandermann H, Rennenberg H (2007) Tree internal signalling and defence reactions under ozone exposure in sun and shade leaves of European beech (Fagus sylvatica L.) trees. Plant Biol 9:253-264. doi:10.1055/s2006-924650 
Joss U, Graber WK (1996) Profiles and simulated exchange of $\mathrm{H}_{2} \mathrm{O}, \mathrm{O}_{3}$, $\mathrm{NO}_{2}$ between the atmosphere and the HartX Scots pine plantation. Theor Appl Climatol 53:157-172. doi:10.1007/bf00866420

Kaakinen S, Kostiainen K, Ek F, Saranpaa P, Kubiske ME, Sober J, Karnosky DF, Vapaavuori E (2004) Stem wood properties of Populus tremuloides, Betula papyrifera and Acer saccharum saplings after 3 years of treatments to elevated carbon dioxide and ozone. Glob Change Biol 10:1513-1525. doi:10.1111/J.13652486.2004.00814.X

Kangasjarvi J, Jaspers P, Kollist H (2005) Signalling and cell death in ozone-exposed plants. Plant Cell Environ 28:1021-1036. doi:10.1111/J.1365-3040.2005.01325.X

Kargiolaki H, Osborne DJ, Thompson FB (1991) Leaf abscission and stem lesions (intumescences) on poplar clones after $\mathrm{SO}_{2}$ and $\mathrm{O}_{3}$ fumigation: a link with ethylene release? J Exp Bot 42:1189-1198. doi:10.1093/jxb/42.9.1189

Karlsson PE, Braun S, Broadmeadow M, Elvira S, Emberson L, Gimeno BS, Le Thiec D, Novak K, Oksanen E, Schaub M, Uddling J, Wilkinson M (2007) Risk assessments for forest trees: the performance of the ozone flux versus the AOT concepts. Environ Pollut 146:608-616. doi:10.1016/j.envpol.2006.06.012

Karlsson PE, Uddling J, Braun S, Broadmeadow M, Elvira S, Gimeno BS, Le Thiec D, Oksanen E, Vandermeiren K, Wilkinson M, Emberson L (2004) New critical levels for ozone effects on young trees based on AOT40 and simulated cumulative leaf uptake of ozone. Atmos Environ 38:2283-2294. doi:10.1016/j. atmosenv.2004.01.027

Karnosky DF, Percy KE, Chappelka AH, Krupa SV (2003) Air pollution and global change impacts on forest ecosystems: monitoring and research needs. In: Air pollution, global change and forests in the new millennium, vol 3. Developments in environmental science. Elsevier science, Amsterdam, pp. 447-459. doi:10.1016/S14748177(03)03025-0

Karnosky DF, Pregitzer KS, Zak DR, Kubiske ME, Hendrey GR, Weinstein D, Nosal M, Percy KE (2005) Scaling ozone responses of forest trees to the ecosystem level in a changing climate. Plant Cell Environ 28:965-981. doi:10.1111/J.13653040.2005.01362.X

Kellomaki S, Wang K (1998) Growth, respiration and nitrogen content in needles of Scots pine exposed to elevated ozone and carbon dioxide in the field. Environ Pollut 101:263-274. doi:10.1016/S0269-7491 (98)00036-0

King JS, Kubiske ME, Pregitzer KS, Hendrey GR, McDonald EP, Giardina CP, Quinn VS, Karnosky DF (2005) Tropospheric $\mathrm{O}_{3}$ compromises net primary production in young stands of trembling aspen, paper birch and sugar maple in response to elevated atmospheric $\mathrm{CO}_{2}$. New Phytol 168:623-635. doi:10.1111/j.1469-8137.2005.01557.x

Kitao M, Low M, Heerdt C, Grams TEE, Haberle KH, Matyssek R (2009) Effects of chronic elevated ozone exposure on gas exchange responses of adult beech trees (Fagus sylvatica) as related to the within-canopy light gradient. Environ Pollut 157:537-544. doi:10.1016/J.Envpol.2008.09.016

Klingberg J, Engardt M, Uddling J, Karlsson PE, Pleijel H (2011) Ozone risk for vegetation in the future climate of Europe based on stomatal ozone uptake calculations. Tellus A 63:174-187. doi:10.1111 jj.1600-0870.2010.00465.x

Koch JR, Creelman RA, Eshita SM, Seskar M, Mullet JE, Davis KR (2000) Ozone sensitivity in hybrid poplar correlates with insensitivity to both salicylic acid and jasmonic acid. The role of programmed cell death in lesion formation. Plant Physiol 123:487-496. doi:10.1104/Pp.123.2.487

Koch JR, Scherzer AJ, Eshita SM, Davis KR (1998) sOzone sensitivity in hybrid poplar is correlated with a lack of defense-gene activation. Plant Physiol 118:1243-1252
Kontunen-Soppela S, Ossipov V, Ossipova S, Oksanen E (2007) Shift in birch leaf metabolome and carbon allocation during long-term openfield ozone exposure. Glob Change Biol 13:1053-1067. doi:10.1111/J.1365-2486.2007.01332.X

Kostiainen K, Kaakinen S, Warsta E, Kubiske ME, Nelson ND, Sober J, Karnosky DF, Saranpaa P, Vapaavuori E (2008) Wood properties of trembling aspen and paper birch after 5 years of exposure to elevated concentrations of $\mathrm{CO}_{2}$ and $\mathrm{O}_{3}$. Tree Physiol 28:805-813. doi:10.1093/treephys/28.5.805

Krause GHM, Arndt U, Brandt CJ, Bucher J, Kenk G, Matzner E (1986) Forest decline in Europe: development and possible causes. Water Air Soil Pollut 31:647-668. doi:10.1007/bf00284218

Küppers K, Klumpp G (1988) Effects of ozone, sulfur dioxide, and nitrogen dioxide on gas exchange and starch economy in Norway spruce (Picea abies [L.] Karsten. GeoJournal 17:271-275. doi:10.1007/BF02432933

Lin M, Fiore AM, Horowitz LW, Cooper OR, Naik V, Holloway J, Johnson BJ, Middlebrook AM, Oltmans SJ, Pollack IB, Ryerson TB, Warner JX, Wiedinmyer C, Wilson J, Wyman B (2012) Transport of Asian ozone pollution into surface air over the western United States in spring. J Geophys Res-Atmos 117:D00V07. doi:10.1029/2011jd016961

Loreto F, Mannozzi M, Maris C, Nascetti P, Ferranti F, Pasqualini $\mathrm{S}$ (2001) Ozone quenching properties of isoprene and its antioxidant role in leaves. Plant Physiol 126:993-1000. doi:10.1104/pp.126.3.993

Loreto F, Pinelli P, Manes F, Kollist H (2004) Impact of ozone on monoterpene emissions and evidence for an isoprene-like antioxidant action of monoterpenes emitted by Quercus ilex leaves. Tree Physiol 24:361-367. doi:10.1093/treephys/24.4.361

LRTAP convention (2004) Manual on methodologies and criteria for modelling and mapping critical loads and levels and air pollution effects, risks and trends. Mapping critial levels for vegetation (Chapter 3). Texte 52/04 (available at http://www.icpmapping. org/Mapping_Manual) pp. Umweltbundesamt, Berlin

LRTAP convention (2010) Manual on methodologies and criteria for modelling and mapping critical loads and levels and air pollution effects, risks and trends. Mapping critial levels for vegetation (Chapter 3). 2010 revision, minor text changes June 2011(available at http://www.icpmapping.org/Mapping Manual)

Ludwikow A, Sadowski J (2008) Gene networks in plant ozone stress response and tolerance. J Integr Plant Biol 50:1256-1267. doi:10.1111/j.1744-7909.2008.00738.x

Lutz C, Anegg S, Gerant D, Alaoui-Sosse B, Gerard J, Dizengremel $\mathrm{P}$ (2000) Beech trees exposed to high $\mathrm{CO}_{2}$ and to simulated summer ozone levels: effects on photosynthesis, chloroplast components and leaf enzyme activity. Physiol Plant 109:252259. doi:10.1034/J.1399-3054.2000.100305.X

Luwe M, Heber U (1995) Ozone detoxification in the apoplasm and symplasm of spinach, broad bean and beech leaves at ambient and elevated concentrations of ozone in air. Planta 197:448-455. doi:10.1007/BF00196666

Manning WJ (2005) Establishing a cause and effect relationship for ambient ozone exposure and tree growth in the forest: progress and an experimental approach. Environ Pollut 137:443-454. doi:10.1016/j.envpol.2005.01.031

Massman WJ (2004) Toward an ozone standard to protect vegetation based on effective dose: a review of deposition resistances and a possible metric. Atmos Environ 38:2323-2337. doi:10.1016/j.atmosenv.2003.09.079

Matyssek R, Günthardt-Goerg MS, Keller T, Scheidegger C (1991) Impairment of gas exchange and structure in birch leaves (Betula pendula) caused by low ozone concentrations. Trees 5:5-13. doi:10.1007/BF00225329 
Matyssek R, Karnosky DF, Wieser G, Percy K, Oksanen E, Grams TEE, Kubiske M, Hanke D, Pretzsch H (2010a) Advances in understanding ozone impact on forest trees: messages from novel phytotron and free-air fumigation studies. Environ Pollut 158:1990-2006. doi:10.1016/j.envpol.2009.11.033

Matyssek R, Le Thiec D, Low M, Dizengremel P, Nunn AJ, Haberle KH (2006) Interactions between drought and $\mathrm{O}_{3}$ stress in forest trees. Plant Biol 8:11-17. doi:10.1055/s-2005-873025

Matyssek R, Maurer S, Gunthardt-Goerg MS, Landolt W, Saurer M, Polle A (1997) Nutrition determines the 'strategy' of Betula pendula for coping with ozone stress. Phyton-Ann Rei Bot A 37:157-167

Matyssek R, Wieser G, Calfapietra C, de Vries W, Dizengremel P, Ernst D, Jolivet Y, Mikkelsen TN, Mohren GMJ, Le Thiec D, Tuovinen JP, Weatherall A, Paoletti E (2012) Forests under climate change and air pollution: gaps in understanding and future directions for research. Environ Pollut 160:57-65. doi:10.1016/j.envpol.2011.07.007

Matyssek R, Wieser G, Ceulemans R, Rennenberg H, Pretzsch H, Haberer K, Low M, Nunn AJ, Werner H, Wipfler P, Osswaldg W, Nikolova P, Hanke DE, Kraigher H, Tausz M, Bahnweg G, Kitao M, Dieler J, Sandermann H, Herbinger K, Grebenc T, Blumenrother M, Deckmyn G, Grams TEE, Heerdt C, Leuchner M, Fabian P, Haberle KH (2010b) Enhanced ozone strongly reduces carbon sink strength of adult beech (Fagus sylvatica) - resume from the free-air fumigation study at Kranzberg Forest. Environ Pollut 158:2527-2532. doi:10.1016/J.Envpol.2010.05.009

Matyssek R, Wieser G, Nunn AJ, Kozovits AR, Reiter IM, Heerdt C, Winkler JB, Baumgarten M, Haberle KH, Grams TEE, Werner H, Fabian P, Havranek WM (2004) Comparison between AOT40 and ozone uptake in forest trees of different species, age and site conditions. Atmos Environ 38:2271-2281. doi:10.1016/j.atmosenv.2003.09.078

McAinsh MR, Evans NH, Montgomery LT, North KA (2002) Calcium signalling in stomatal responses to pollutants. New Phytol 153:441-447

McLaughlin SB, Nosal M, Wullschleger SD, Sun G (2007) Interactive effects of ozone and climate on tree growth and water use in a southern Appalachian forest in the USA. New Phytol 174:109124. doi:10.1111/j.1469-8137.2007.02018.x

Miller J, Arteca R, Pell E (1999) Senescence-associated gene expression during ozone-induced leaf senescence in Arabidopsis. Plant Physiol 120:1015-1023. doi:10.1104/pp.120.4.1015

Miller PR, Arbaugh MJ, Temple PJ (1997) Ozone and its known and potential effects on forests in western United States. In: Sandermann H, Wellburn A, Heath R (eds) Forest decline and ozone, vol 127. Ecological studies. Springer, Berlin Heidelberg, pp. 39-67. doi:10.1007/978-3-642-59233-1_2

Miller PR, de Bauer ML, Quevedo-Nolasco A, Hernandez-Tejeda T (1994) Comparison of ozone exposure characteristics in forested regions near Mexico City and Los Angeles. Atmos Environ 28: 141-148. doi:10.1016/1352-2310(94)90029-9

Mills G, Wagg S, Harmens H (2013) Ozone pollution: impacts on ecosystem services and biodiversity. ICP Vegetation Programme Coordination Centre. Centre for Ecology and Hydrology, Bangor, UK

Mittler R (2002) Oxidative stress, antioxidants and stress tolerance. Trends Plant Sci 7:405-410. doi:10.1016/S1360-1385(02)02312-9

Mittler R, Vanderauwera S, Gollery M, Van Breusegem F (2004) Reactive oxygen gene network of plants. Trends Plant Sci 9:490498. doi:10.1016/j.tplants.2004.08.009

Monks PS, Archibald AT, Colette A, Cooper O, Coyle M, Derwent R, Fowler D, Granier C, Law KS, Mills GE, Stevenson DS, Tarasova O, Thouret V, von Schneidemesser E, Sommariva R, Wild O, Williams ML (2015) Tropospheric ozone and its precursors from the urban to the global scale from air quality to short-lived climate forcer. Atmos Chem Phys 15:8889-8973. doi:10.5194/acp-15-8889-2015
Moura BB, de Souza SR, Alves ES (2014) Response of Brazilian native trees to acute ozone dose. Environ Sci Pollut R 21:4220-4227. doi:10.1007/s11356-013-2326-1

Musselman RC, Lefohn AS, Massman WJ, Heath RL (2006) A critical review and analysis of the use of exposure- and flux-based ozone indices for predicting vegetation effects. Atmos. Environ. 40:18691888. doi:10.1016/j.atmosenv.2005.10.064

Navrot N, Collin V, Gualberto J, Gelhaye E, Hirasawa M, Rey P, Knaff DB, Issakidis E, Jacquot JP, Rouhier N (2006) Plant glutathione peroxidases are functional peroxiredoxins distributed in several subcellular compartments and regulated during biotic and abiotic stresses. Plant Physiol 142:1364-1379. doi:10.1104/pp.106.089458

Neirynck J, Gielen B, Janssens IA, Ceulemans R (2012) Insights into ozone deposition patterns from decade-long ozone flux measurements over a mixed temperate forest. J Environ Monit 14:1684 1695. doi:10.1039/c2em10937a

Nikolova PS, Andersen CP, Blaschke H, Matyssek R, Haberle KH (2010) Belowground effects of enhanced tropospheric ozone and drought in a beech/spruce forest (Fagus sylvatica L./Picea abies [L.] Karst. Environ Pollut 158:1071-1078. doi:10.1016/j.envpol.2009.07.036

Noctor G (2006) Metabolic signalling in defence and stress: the central roles of soluble redox couples. Plant Cell Environ 29:409-425. doi:10.1111/j.1365-3040.2005.01476.x

Noctor G, Mhamdi A, Chaouch S, Han Y, Neukermans J, MarquezGarcia B, Queval G, Foyer CH (2012) Glutathione in plants: an integrated overview. Plant Cell Environ 35:454-484. doi:10.1111/j.1365-3040.2011.02400.x

Noormets A, McDonald EP, Dickson RE, Kruger EL, Sober A, Isebrands JG, Karnosky DF (2001) The effect of elevated carbon dioxide and ozone on leaf- and branch-level photosynthesis and potential plant-level carbon gain in aspen. Trees 15:262-270. doi:10.1007/S004680100102

Nunn AJ, Cieslik S, Metzger U, Wieser G, Matyssek R (2010) Combining sap flow and eddy covariance approaches to derive stomatal and non-stomatal $\mathrm{O}_{3}$ fluxes in a forest stand. Environ Pollut 158:2014-2022. doi:10.1016/j.envpol.2009.11.034

Nunn AJ, Kozovits AR, Reiter IM, Heerdt C, Leuchner M, Lutz C, Liu X, Low M, Winkler JB, Grams TEE (2005) Comparison of ozone uptake and sensitivity between a phytotron study with young beech and a field experiment with adult beech (Fagus sylvatica. Environ Pollut 137:494-506

Oksanen E, Haikio E, Sober J, Karnosky DF (2004) Ozone-induced $\mathrm{H}_{2} \mathrm{O}_{2}$ accumulation in field-grown aspen and birch is linked to foliar ultrastructure and peroxisomal activity. New Phytol 161:791-799. doi:10.1111/J.1469-8137.2003.00981.X

Oksanen E, Kontunen-Soppela S, Riikonen J, Peltonen P, Uddling J, Vapaavuori E (2007) Northern environment predisposes birches to ozone damage. Plant Biol 9:191-196. doi:10.1055/s-2006-924176

Oksanen E, Riikonen J, Kaakinen S, Holopainen T, Vapaavuori E (2005) Structural characteristics and chemical composition of birch (Betula pendula) leaves are modified by increasing $\mathrm{CO}_{2}$ and ozone. Glob Change Biol 11:732-748. doi:10.1111/j.1365-2486.2005.00938.x

Olbrich M, Betz G, Bahnweg G, Welzl G, Ernst D (2010a) Effects of abiotic and biotic stress on gene transcription in European beech (Fagus sylvatica L.): from saplings to mature beech trees. J Biotechnol 150:S120-S121

Olbrich M, Betz G, Gerstner E, Langebartels C, Sandermann H, Ernst D (2005) Transcriptome analysis of ozone-responsive genes in leaves of European beech (Fagus sylvatica L. Plant Biol 7:670-676. doi:10.1055/s-2005-873001

Olbrich M, Knappe C, Wenig M, Gerstner E, Haberle KH, Kitao M, Matyssek R, Stich S, Leuchner M, Werner H, Schlink K, MullerStarck G, Welzl G, Scherb H, Ernst D, Heller W, Bahnweg G (2010b) Ozone fumigation (twice ambient) reduces leaf infestation following natural and artificial inoculation by the endophytic fungus 
Apiognomonia errabunda of adult European beech trees. Environ Pollut 158:1043-1050. doi:10.1016/j.envpol.2009.09.020

Ollinger SV, Aber JD, Reich PB (1997) Simulating ozone effects on forest productivity: interactions among leaf-, canopy-, and standlevel processes. Ecol Appl 7:1237-1251

Oltmans SJ, Lefohn AS, Shadwick D, Harris JM, Scheel HE, Galbally I, Tarasick DW, Johnson BJ, Brunke EG, Claude H, Zeng G, Nichol S, Schmidlin F, Davies J, Cuevas E, Redondas A, Naoe H, Nakano T, Kawasato T (2013) Recent tropospheric ozone changes - a pattern dominated by slow or no growth. Atmos Environ 67:331-351. doi:10.1016/j.atmosenv.2012.10.057

Pääkkönen E, Seppänen S, Holopainen T, Kokko H, Kärenlampi S, Kärenlampi L, Kangasjärvi J (1998a) Induction of genes for the stress proteins PR-10 and PAL in relation to growth, visible injuries and stomatal conductance in birch (Betula pendula) clones exposed to ozone and/or drought. New Phytol 138:295-305. doi:10.1046/j.1469-8137.1998.00898.x

Pääkkönen E, Vahala J, Pohjolai M, Holopainen T, Karenlampi L (1998b) Physiological, stomatal and ultrastructural ozone responses in birch (Betula pendula Roth.) are modified by water stress. Plant Cell Environ 21:671-684. doi:10.1046/j.1365-3040.1998.00303.x

Padro J (1996) Summary of ozone dry deposition velocity measurements and model estimates over vineyard, cotton, grass and deciduous forest in summer. Atmos Environ 30:2363-2369. doi:10.1016/1352-2310(95)00352-5

Padu E, Kollist H, Tulva I, Oksanen E, Moldau H (2005) Components of apoplastic ascorbate use in Betula pendula leaves exposed to $\mathrm{CO}_{2}$ and $\mathrm{O}_{3}$ enrichment. New Phytol 165: 131-141. doi:10.1111/j.1469-8137.2004.01220.x

Paoletti E (2005) Ozone slows stomatal response to light and leaf wounding in a Mediterranean evergreen broadleaf, Arbutus unedo. Environ Pollut 134:439-445. doi:10.1016/j.envpol.2004.09.011

Paoletti E, Grulke NE (2010) Ozone exposure and stomatal sluggishness in different plant physiognomic classes. Environ Pollut 158:2664 2671. doi:10.1016/j.envpol.2010.04.024

Pell E, Sinn J, Brendley B, Samuelson L, Vinten-Johansen C, Tien M, Skillman J (1999) Differential response of four tree species to ozoneinduced acceleration of foliar senescence. Plant Cell Environ 22: 779-790. doi:10.1046/J.1365-3040.1999.00449.X

Pell EJ, Eckardt N, Enyedi AJ (1992) Timing of ozone stress and resulting status of ribulose bisphosphate carboxylase/ oxygenase and associated net photosynthesis. New Phytol 120: 397-405. doi:10.1111/J.1469-8137.1992.Tb01080.X

Pell EJ, Landry LG, Eckardt NA, Glick RE (1994) Air pollution and RubisCO: effects and implications. In: Alsher RG, Wellburn AR (eds) Plant responses to the gaseous environment. Chapman \&Hall, London, pp. 239-254. doi:10.1007/978-94-011-1294-9_13

Pellinen R, Palva T, Kangasjarvi J (1999) Subcellular localization of ozone-induced hydrogen peroxide production in birch (Betula pendula) leaf cells. Plant J 20:349-356. doi:10.1046/j.1365-313X.1999.00613.x

Pellinen RI, Korhonen MS, Tauriainen AA, Palva ET, Kangasjarvi J (2002) Hydrogen peroxide activates cell death and defense gene expression in birch. Plant Physiol 130:549-560. doi:10.1104/pp.003954

Pelloux J, Jolivet Y, Fontaine V, Banvoy J, Dizengremel P (2001) Changes in Rubisco and Rubisco activase gene expression and polypeptide content in Pinus halepensis M. subjected to ozone and drought. Plant Cell Environ 24:123-131. doi:10.1046/J.1365-3040.2001.00665.X

Peltonen PA, Vapaavuori E, Julkunen-tiitto R (2005) Accumulation of phenolic compounds in birch leaves is changed by elevated carbon dioxide and ozone. Glob Change Biol 11:1305-1324. doi:10.1111/J.1365-2486.2005.00979.X

Percy KE, Awmack CS, Lindroth RL, Kubiske ME, Kopper BJ, Isebrands JG, Pregitzer KS, Hendrey GR, Dickson RE, Zak DR,
Oksanen E, Sober J, Harrington R, Karnosky DF (2002) Altered performance of forest pests under atmospheres enriched by $\mathrm{CO}_{2}$ and $\mathrm{O}_{3}$. Nature 420:403-407. doi:10.1038/Nature01028

Pleijel H, Danielsson H, Vandermeiren K, Blum C, Colls J, Ojanpera K (2002) Stomatal conductance and ozone exposure in relation to potato tuber yield - results from the European CHIP programme. Eur J Agron 17:303-317. doi:10.1016/s1161-0301(02)00068-0

Polle A, Wieser G, Havranek WM (1995) Quantification of ozone influx and apoplastic ascorbate content in needles of Norway spruce trees (Picea abies L., Karst) at high altitude. Plant Cell Environ 18:681688. doi:10.1111/J.1365-3040.1995.Tb00569.X

Pretzsch H, Dieler J, Matyssek R, Wipfler P (2010) Tree and stand growth of mature Norway spruce and European beech under long-term ozone fumigation. Environ Pollut 158:1061-1070. doi:10.1016/j.envpol.2009.07.035

Pritsch K, Esperschuetz J, Haesler F, Raidl S, Winkler B, Schloter M (2009) Structure and activities of ectomycorrhizal and microbial communities in the rhizosphere of Fagus sylvatica under ozone and pathogen stress in a lysimeter study. Plant Soil 323:97-109. doi:10.1007/s11104-009-9972-6

Proietti C, Anav A, De Marco A, Sicard P, Vitale M (2016) A multi-sites analysis on the ozone effects on gross primary production of European forests. Sci Total Environ 556:1-11. doi:10.1016/j.scitotenv.2016.02.187

Rangnekar PV, Forward DF (1969) Foliar nutrition and growth in red pine: the fate of photoassimilated carbon in a seedling tree. Can J Bot 47:897-906. doi:10.1139/b69-129

Ranieri A, Castagna A, Padu E, Moldau H, Rahi M, Soldatini GF (1999) The decay of $\mathrm{O}_{3}$ through direct reaction with cell wall ascorbate is not sufficient to explain the different degrees of $\mathrm{O}_{3}$ sensitivity in two poplar clones. J Plant Physiol 154:250-255. doi:10.1016/S0176-1617(99)80216-8

Rannik U, Altimir N, Mammarella I, Back J, Rinne J, Ruuskanen TM, Hari P, Vesala T, Kulmala M (2012) Ozone deposition into a boreal forest over a decade of observations: evaluating deposition partitioning and driving variables. Atmos Chem Phys 12:1216512182. doi:10.5194/acp-12-12165-2012

Reich PB (1983) Effects of low concentrations of $\mathrm{O}_{3}$ on net photosynthesis dark respiration, and chlorophyll contents in aging hybrid poplar leaves. Plant Physiol 73:291-296. doi:10.1104/pp.73.2.291

Reich PB (1987) Quantifying plant response to ozone: a unifying theory. Tree Physiol 3:63-91. doi:10.1093/treephys/3.1.63

Reich PB, Lassoie JP, Amundson RG (1984) Reduction in growth of hybrid poplar following field exposure to low-levels of $\mathrm{O}_{3}$ and (or) $\mathrm{SO}_{2}$. Can J Bot 62:2835-2841

Renaut J, Bohler S, Hausman JF, Hoffmann L, Sergeant K, Ahsan N, Jolivet Y, Dizengremel P (2009) The impact of atmospheric composition on plants: a case study of ozone and poplar. Mass Spectrom Rev 28:495-516. doi:10.1002/mas.20202

Rennenberg H, Herschbach C, Polle A (1996) Consequences of air pollution on shoot-root interactions. J Plant Physiol 148:296-301. doi:10.1016/S0176-1617(96)80256-2

Ribas A, Penuelas J, Elvira S, Gimeno BS (2005) Ozone exposure induces the activation of leaf senescence-related processes and morphological and growth changes in seedlings of Mediterranean tree species. Environ Pollut 134:291-300. doi:10.1016/j.envpol.2004.07.026

Richet N, Afif D, Huber F, Pollet B, Banvoy J, El Zein R, Lapierre C, Dizengremel P, Perré P, Cabané M (2011) Cellulose and lignin biosynthesis is altered by ozone in wood of hybrid poplar (Populus tremula x alba. J Exp Bot 62:3575-3586. doi:10.1093/jxb/err047

Richet N, Tozo K, Afif D, Banvoy J, Legay S, Dizengremel P, Cabané M (2012) The response to daylight or continuous ozone of phenylpropanoid and lignin biosynthesis pathways in poplar differs between leaves and wood. Planta 236:727-737. doi:10.1007/s00425-012-1644-8 
Rosemann D, Heller W, Sandermann H Jr (1991) Biochemical plant responses to ozone. II. Induction of stilbene biosynthesis in Scots pine (Pinus sylvestris L.) seedlings. Plant Physiol 97:1280-1286. doi:10.1104/pp.97.4.1280

Rouhier N (2010) Plant glutaredoxins: pivotal players in redox biology and iron-sulphur centre assembly. New Phytol 186(2):365-372. doi:10.1111/j.1469-8137.2009.03146.x

Rouhier N, Jacquot JP (2005) The plant multigenic family of thiol peroxidases. Free Radical Bio Med 38:1413-1421. doi:10.1016/j.freebiomed.2004.07.037

Royal Society (2008) Ground-level ozone in the 21st century: future trends, impacts and policy implications. $132 \mathrm{pp}$. Science Policy report $15 / 08$. Royal Society, London

Samuel MA, Miles GP, Ellis BE (2000) Ozone treatment rapidly activates MAP kinase signalling in plants. Plant J 22:367-376. doi:10.1046/j.1365-313x.2000.00741.x

Samuelson L, Kelly JM (2001) Scaling ozone effects from seedlings to forest trees. New Phytol 149:21-41. doi:10.1046/j.1469-8137.2001.00007.x

Sandermann H, Wellburn A, Heath R (1997) Forest decline and ozone vol 127.400 pp. Ecological Studies. Springer, Berlin Heidelberg

Saxe H (2002) Physiological responses of trees to ozone - interactions and mechanisms. Curr Top. Plant Biol 3:27-55

Sehmer L, Fontaine V, Antoni F, Dizengremel P (1998) Effects of ozone and elevated atmospheric carbon dioxide on carbohydrates metabolism of spruce needles. Catabolic and detoxification pathways. Physiol Plant 102:605-611. doi:10.1034/j.1399-3054.1998.1020416.x

Sharkey TD, Wiberley AE, Donohue AR (2008) Isoprene emission from plants: why and how. Ann Bot 101:5-18. doi:10.1093/aob/mcm240

Singh HB (1987) Reactive nitrogen in the troposphere. Environ Sci Technol 21:320-327. doi:10.1021/es00158a001

Sitch S, Cox PM, Collins WJ, Huntingford C (2007) Indirect radiative forcing of climate change through ozone effects on the land-carbon sink. Nature 448:791-794. doi:10.1038/Nature06059

Skärby L, Troeng E, Bostroem C (1987) Ozone uptake and effects on transpiration, net photosynthesis, and dark respiration in Scots pine. For Sci 33:801-808

Skelly JM, Fredericksen TS, Savage JE, Snyder KR (1996) Vertical gradients of ozone and carbon dioxide within a deciduous forest in central Pennsylvania. Environ Pollut 94:235-240. doi:10.1016/s0269-7491(96)00108-x

Skelly JM, Savage JE, deBauer MD, Alvarado D (1997) Observations of ozone-induced foliar injury on black cherry (Prunus serotina, var. Capuli) within the Desierto de Los Leones National Park, Mexico City. Environ Pollut 95: 155-158. doi:10.1016/s0269-7491(96)00121-2

Spence RD, Rykiel EJ Jr, Sharpe PJ (1990) Ozone alters carbon allocation in loblolly pine: assessment with carbon-11 labeling. Environ Pollut 64:93-106. doi:10.1016/0269-7491(90)90107-N

Steffen W, Persson A, Deutsch L, Zalasiewicz J, Williams M, Richardson K, Crumley C, Crutzen P, Folke C, Gordon L, Molina M, Ramanathan V, Rockstrom J, Scheffer M, Schellnhuber HJ, Svedin U (2011) The anthropocene: from global change to planetary stewardship. Ambio 40:739-761. doi:10.1007/s13280-011-0185-x

Stockwell WR, Kramm G, Scheel HE, Mohnen VA, Seiler W (1997) Ozone formation, destruction and exposure in Europe and the United States. In: Sandermann H, Wellburn A, Heath R (eds) Forest decline and ozone, vol 127. Ecological Studies. Springer, Berlin Heidelberg, pp. 1-38. doi:10.1007/978-3-642-59233-1 1

Stohl A, Eckhardt S (2004) Intercontinental transport of air pollutantsdesert dust, biomass burning and anthropogenic sources vol $4 \mathrm{pp}$. The handbook of environmental chemistry - air pollution. SpringerVerlag, Berlin

Strohm M, Eiblmeier M, Langebartels C, Jouanin L, Polle A, Sandermann H, Rennenberg H (2002) Responses of antioxidative systems to acute ozone stress in transgenic poplar (Populus tremula $\mathrm{x} P$. alba) over-expressing glutathione synthetase or glutathione reductase. Trees 16:262-273. doi:10.1007/s00468-001-0157-z

Subramanian N, Karlsson PE, Bergh J, Nilsson U (2015) Impact of ozone on sequestration of carbon by swedish forests under a changing climate: a modeling study. For Sci 61:445-457. doi: 10.5849 /forsci.14-026

Tausz M, Olszyk DM, Monschein S, Tingey DT (2004) Combined effects of $\mathrm{CO}_{2}$ and $\mathrm{O}_{3}$ on antioxidative and photoprotective defense systems in needles of ponderosa pine. Biol Plant 48:543-548. doi:10.1023/B:BIOP.0000047150.82053.e9

Telewski FW (1992) Ethylene production by different age class ponderosa and jeffery pine needles as related to ozone exposure and visible injury. Trees 6:195-198. doi:10.1007/BF00224335

Tingey DT, Wilhour RG, Standley C (1976) The effect of chronic ozone exposures on the metabolite content of ponderosa pine seedlings. For Sci 22:234-241

Tjoelker MG, Volin JC, Oleksyn J, Reich PB (1994) An open-air system for exposing forest-canopy branches to ozone pollution. Plant Cell Environ 17:211-218. doi:10.1111/j.1365-3040.1994.tb00285.x

Tuomainen J, Pellinen R, Roy S, Kiiskinen M, Eloranta T, Karjalainen R, Kangasjarvi J (1996) Ozone affects birch (Betula pendula Roth) phenylpropanoid, polyamine and active oxygen detoxifying pathways at biochemical and gene expression level. J Plant Physiol 148:179-188. doi:10.1016/S0176-1617(96)80312-9

Tuovinen J-P, Emberson L, Simpson D (2009) Modelling ozone fluxes to forests for risk assessment: status and prospects. Ann For Sci 66. doi:10.1051/Forest/2009024

Uddling J, Hogg AJ, Teclaw RM, Carroll MA, Ellsworth DS (2010) Stomatal uptake of $\mathrm{O}_{3}$ in aspen and aspen-birch forests under freeair $\mathrm{CO}_{2}$ and $\mathrm{O}_{3}$ enrichment. Environ Pollut 158:2023-2031. doi:10.1016/j.envpol.2009.12.001

Uddling J, Teclaw RM, Pregitzer KS, Ellsworth DS (2009) Leaf and canopy conductance in aspen and aspen-birch forests under freeair enrichment of carbon dioxide and ozone. Tree Physiol 29: 1367-1380. doi:10.1093/treephys/tpp070

Vahala J, Keinanen M, Schutzendubel A, Polle A, Kangasjarvi J (2003a) Differential effects of elevated ozone on two hybrid aspen genotypes predisposed to chronic ozone fumigation. Role of ethylene and salicylic acid. Plant Physiol 132:196-205. doi:10.1104/pp.102.018630

Vahala J, Ruonala R, Keinanen M, Tuominen H, Kangasjarvi J (2003b) Ethylene insensitivity modulates ozone-induced cell death in birch. Plant Physiol 132:185-195. doi:10.1104/pp.102.018887

Vahisalu T, Puzorjova I, Brosche M, Valk E, Lepiku M, Moldau H, Pechter P, Wang YS, Lindgren O, Salojarvi J, Loog M, Kangasjarvi J, Kollist H (2010) Ozone-triggered rapid stomatal response involves the production of reactive oxygen species, and is controlled by SLAC1 and OST1. Plant J 62:442-453. doi:10.1111/J.1365-313x.2010.04159.X

Vainonen JP, Kangasjarvi J (2014) Plant signalling in acute ozone exposure. Plant Cell Environ. doi:10.1111/pce.12273

Vaultier M-N, Jolivet Y (2015) Ozone sensing and early signaling in plants: an outline from the cloud. Environ Exp Bot. doi:10.1016/j.envexpbot.2014.11.012

Wang B, Shugart HH, Shuman JK, Lerdau MT (2016) Forests and ozone: productivity, carbon storage, and feedbacks. Sci Rep 6 . doi:10.1038/srep2213322133

Weidmann P, Einig W, Egger B, Hampp R (1990) Contents of ATP and ADP in needles of Norway spruce in relation to their development, age, and to symptoms of forest decline. Trees 4:68-74. doi:10.1007/BF00226068

Wellburn FAM, Lau KK, Milling PMK, Wellburn AR (1996) Drought and air pollution affect nitrogen cycling and free radical scavenging in Pinus halepensis (Mill. J Exp Bot 47:1361-1367. doi: $10.1093 / \mathrm{jxb} / 47.9 .1361$ 
Wesely ML, Hicks BB (2000) A review of the current status of knowledge on dry deposition. Atmos Environ 34:2261-2282. doi:10.1016/S1352-2310(99)00467-7

Wieser G, Havranek WM (1993) Ozone uptake in the sun and shade crown of spruce: quantifying the physiological effects of ozone exposure. Trees 7:227-232. doi:10.1007/BF00202078

Wieser G, Hecke K, Tausz M, Matyssek R (2013) Foliage type specific susceptibility to ozone in Picea abies, Pinus cembra and Larix decidua at treeline: a synthesis. Environ Exp Bot 90:4-11. doi:10.1016/j.envexpbot.2012.09.013

Wieser G, Matyssek R, Gotz B, Grunhage L (2012) Branch cuvettes as means of ozone risk assessment in adult forest tree crowns: combining experimental and modelling capacities. Trees 26:1703-1712. doi:10.1007/s00468-012-0715-6

Wieser G, Matyssek R, Then C, Cieslik S, Paoletti E, Ceulemans R (2008) Upscaling ozone flux in forests from leaf to landscape. Ital J Agron 3:35-41. doi:10.4081/ija.2008.35

Wittig VE, Ainsworth EA, Long SP (2007) To what extent do current and projected increases in surface ozone affect photosynthesis and stomatal conductance of trees? A meta-analytic review of the last 3 decades of experiments. Plant Cell Environ 30:1150-1162. doi:10.1111/j.1365-3040.2007.01717.x

Wittig VE, Ainsworth EA, Naidu SL, Karnosky DF, Long SP (2009) Quantifying the impact of current and future tropospheric ozone on tree biomass, growth, physiology and biochemistry: a quantitative meta-analysis. Glob Change Biol 15:396-424. doi:10.1111/J.1365-2486.2008.01774.X

Wustman BA, Oksanen E, Karnosky DF, Noormets A, Isebrands JG, Pregitzer KS, Hendrey GR, Sober J, Podila GK (2001) Effects of elevated $\mathrm{CO}_{2}$ and $\mathrm{O}_{3}$ on aspen clones varying in $\mathrm{O}_{3}$ sensitivity: can $\mathrm{CO}_{2}$ ameliorate the harmful effects of $\mathrm{O}_{3}$ ? Environ Pollut 115:473481. doi:10.1016/S0269-7491(01)00236-6

Yamaji K, Julkunen-Tiitto R, Rousi M, Freiwald V, Oksanen E (2003) Ozone exposure over two growing seasons alters root-to-shoot ratio and chemical composition of birch (Betula pendula Roth. Glob Change Biol 9:1363-1377. doi:10.1046/J.1365-2486.2003.00669.X

Yun S, Laurence J (1999) The response of clones of Populus tremuloides differing in sensitivity to ozone in the field. New Phytol 141:411421. doi:10.1046/J.1469-8137.1999.00359.X

Zhang L, Vet R, Brook JR, Legge AH (2006) Factors affecting stomatal uptake of ozone by different canopies and a comparison between dose and exposure. Sci Total Environ 370:117-132. doi:10.1016/j.scitotenv.2006.06.004

Zinser C, Ernst D, Sandermann HJ (1998) Induction of stilbene synthase and cinnamyl alcohol dehydrogenase mRNAs in Scots pine (Pinus sylvestris L.) seedlings. Planta 204:169-176. doi:10.1007/S004250050243 